CUPAUAM. 16-1989, 169-210

\title{
EL VASO TEROMORFO DEL POBLADO GRANDE DE TOSSAL REDO (CALACEITE, TERUEL) Y SU CONTEXTO ARQUEOLOGICO
}

\author{
Ma. Rosario Lucas Pellicer \\ Universidad AUTONOMA DE MADRID
}

\section{Resumen}

Se discuten las propuestas sobre el origen del modelo y se formula la hipótesis de la vía italiana. El contexto une materiales autóctonos con otros de raíz europea y colonial. Se llega a la conclusión de que el lugar del hallazgo tenía un destino religioso.

\section{Summary}

We discuss the diferent proposals about the provenance of this particular type of decorated vessel, and we put forward the hypothesis of an Italian origin. The context in which the vase from Tossal Redo was found contained indigenous products in association with others of european and colonial origin. The conclusion is reached that the finding place had a religious function.

La temprana manifestación de la cultura ibérica en el Bajo Ebro está documentada por una serie de materiales de raigambre mediterránea, valorados justamente como indicadores de la marcha del proceso cultural y del efecto de las relaciones externas. En concreto, la filiación y paralelos recabados por E. Sanmartí (1975 y 1978) para la vasija anforoide del Pobado Grande de Tossal Redó (Calaceite, Teruel) llevan a situar este yacimiento en la Fase II del Horizonte Ibérico Antiguo, fechada entre 550 - 520 (Sanmartí y Padró, 1978, 67). Por su parte, M. Pellicer (1984, 220 -222) incluye entre el componente orientalizante del Nordeste Hispano, el vaso teromorfo procedente del mismo poblado, considerado tradicionalmente como de influjo céltico o hallstáttico.

Dado el estado de la cuestión, se aportan en este artículo algunos datos con el fin de matizar el valor cultural de tan singular vasija y de los materiales asociados a un mismo contexto.

\section{CIRCUNSTANCIAS DEL HALLAZGO}

En el cabezo de Tossal Redó, término de Calaceite (Teruel) existen ruinas de dos poblados bien diferenciados. El vaso teromorfo (Fig. 3) procede del situado en la cima, organizado en 
calle axial y conocido como Poblado Grande del Tossal Redó, en contraposición al poblado Pequeño (o Bajo), más antiguo y de estructuras yuxtapuestas, asentado en una reducida meseta, a menor altura.

El emplazamiento (Fig. 1) está a medio camino entre los ríos Matarraña y Algá, afluentes de la margen derecha del Ebro, y dentro de un núcleo denso de yacimientos, temprano objetivo de las investigaciones arqueológicas emprendidas por el Institut d'Estudis Catalans bajo la dirección de D. Pedro Bosch Gimpera y la incondicional colaboración de un esforzado grupo de arqueólogos y aficionados locales.

En el Diari de Excavaciones, manuscrito en catalán por el propio Bosch Gimpera, consta que los días 16 y 17 de octubre de 1914, tras excavar el poblado de la Gessera, realizó una excavación de prueba en Tossal Redó "Alt". Los resultados, incluyendo los croquis de campo, quedan registrados en las correspondientes páginas (Apéndice final) dándose la paradoja de que los folios dedicados a esta exploración preliminar (Pág. 27 a 29) y al inventario de los materiales (Pág. 39 a 45) son más numerosos y detallados que los referentes a la excavación completa de los dos poblados (1).

El lugar elegido para la excavación de tanteo se sitúa en la zona Noroeste de la plataforma amesetada, espacio que más tarde se denominará Cambra o Habitación 1.

En este sector se descubrieron dos largos muros de $30 \mathrm{~cm}$. de ancho formados por aparejo de piedras secas trabadas con barro y un alzado máximo de $65 \mathrm{~cm}$. Según el croquis, ambas paredes se unían en ángulo recto y apoyaban directamente sobre la roca. En el interior existía un desnivel formando una especie de banco, elevado unos $45 \mathrm{~cm}$. sobre el piso natural (todo ello labrado en roca viva). La textura del relleno, desde la superficie a la roca, se especifica en los siguientes términos:

1: Hasta $20 \mathrm{~cm}$. tierra vegetal negruzca.

2: Capa de tierras más claras con argamasa y restos informes de adobes.

3: Tierra quemada, ennegrecida con carbones. Profundidad variable (generalmente $5 \mathrm{~cm}$.).

En el centro de la habitación la profundidad señalada para cada capa corresponde respectivamente a 40,50 y $20 \mathrm{~cm}$. hasta alcanzar un total de $1,10 \mathrm{~m}$. de relleno.

(1) Quiero hacer constar mi agradecimiento al Profesor Eduardo Ripoll por toda la atención dispensada durante mi estancia en el Museo Arqueológico de Barcelona. Se me permitió la libre consulta del Diario de Bosh Gimpera y el estudio directo de los materiales. Pese a las muchas ocupaciones de su cargo como Director, atendió siempre con enorme paciencia mis consultas y realizó personalmente algunas de las fotografías que acompañan estas páginas. Esta gratitud es extensible a todo el personal del Museo, así como al Dr. Sanmartí que me remitió las páginas fotocopiadas que aquí se adjuntan.

La fortuna ha querido que este artículo no apareciera en el número anterior y ello me ha brindado, además de su dedicación a una compañera y amiga tan entrañable como $\mathrm{M}^{\mathrm{a}}$. Angeles Alonso, la ocasión de volver, una vez más, al Museo de Barcelona. El actual director, Dr. Ricardo Batista, y la Conservadora Dña. Teresa Carreras me han atendido con enorme amabilidad y diligencia. Mi deuda de gratitud sigue en aumento. 


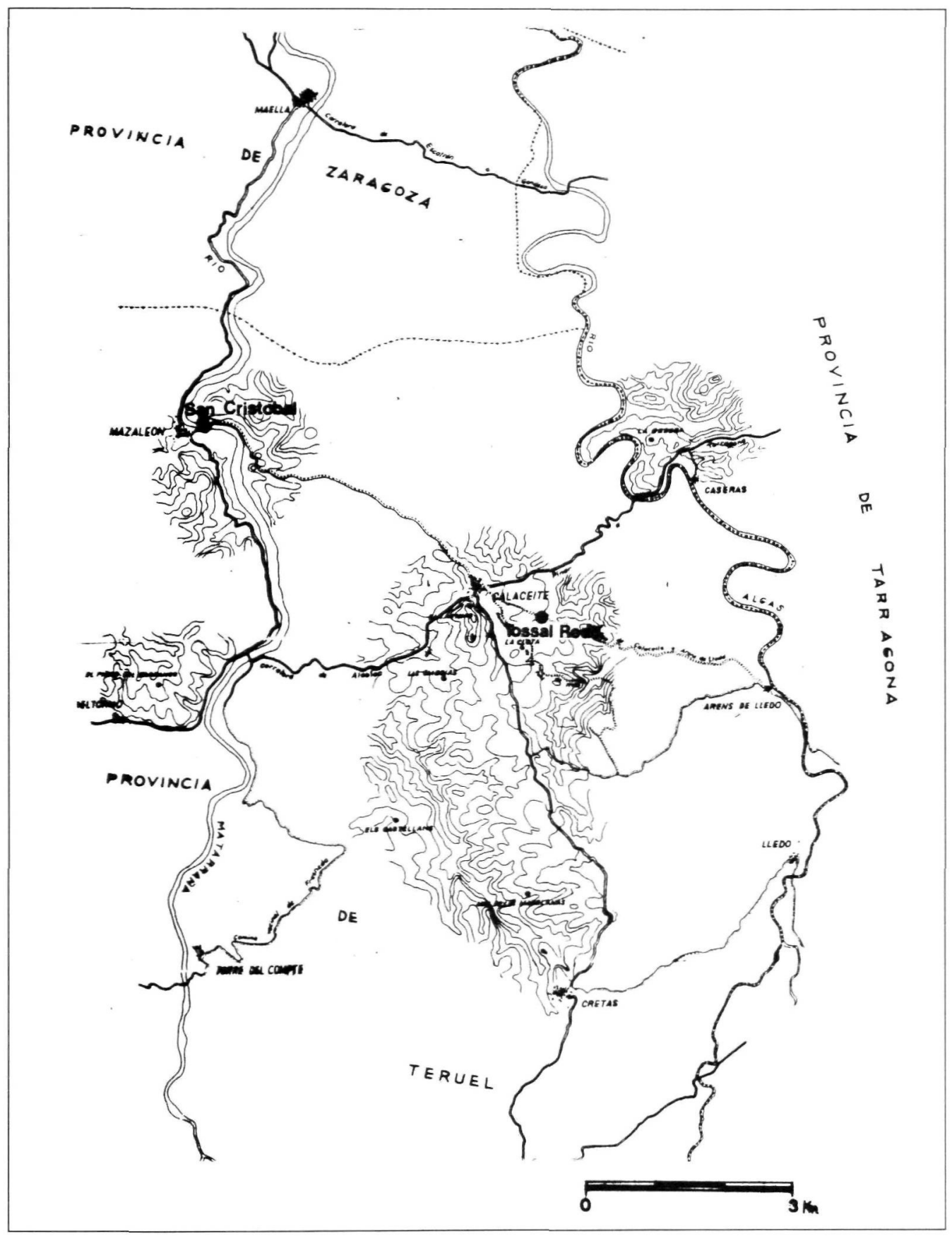

Figura 1. Localización del poblado de Tossal Redó (Calaceite, Teruel). 


\section{Materiales inventariados}

En la capa superficial (1a.) se menciona el hallazgo de un vasito de $6 \mathrm{~cm}$. de altura carente de borde (inventariado con el núm. 327), hecho a mano y de superficie negra y pulida (Fig. 2,4 y Lám. IV, 2).

De la capa 2a. procede la pata de taula de fanc, identificada como el fragmento de una curiosa mesa (Lám.III y Fig. 2, 7) de barro tosco mezclado con paja (Inv. 322). En el mismo nivel se recogieron fragmentos de cerámica a mano decorada, de color negruzco (Inv. 332) y numerosos fragmentos "en desorden". Según se apostilla más adelante algunos de ellos pertenecían al vaso con cabeza de animal cuyos restos más representativos se localizaron en la capa 3, la más profunda.

Justamente en este último nivel, es decir la tercera capa, se recuperaron, junto a las paredes y a cierta distancia de la esquina, fragmentos de barro tosco (Inv. 311-314) decorados con acanalados geométricos (Fig.2,6) y en el centro de la estancia los fragmentos de un vaso con cuello cilíndrico y dos asas (Inv. 307) (Lám. III,3). Entre las tierras que rellenaban este recipiente apareció el brazalete de bronce (Inv. 310: fig.2,1) y un fragmento de hierro (Inv. 310) descrito como plaquita circular y dibujado con dos pequeños apéndices. Se alude también a la existencia de madera carbonizada (Inv. 302-303) y a la presencia en toda la capa de fragmentos de fanc bermellón pulit pintat, un d'ell de la vora amb un cap d'animal per ansa idénticos a los que se habían recogido en la capa 2a. Este recipiente teromorfo se inventaría ya restaurado (Núm. 316) consignando su altura $(22 \mathrm{~cm}$.) y sus características : a mano, pasta rojiza y decoración pintada (Lám. I, Fig.3, 1).

También se especifica que al repasar las tierras de esta capa 3 se recuperó un broche de cinturón de bronce (Inv. 305; Fig..2, 2) y un botón del mismo metal, inventariado con el núm. 306 y dibujado en su anverso y reverso (Fig.2,3), además de otros fragmentos de bronce informes (Inv. 308-309) y aspecto laminar.

Al final se añade que, en desorden y por todas las capas, aparecieron otros fragmentos de cerámicas (a mano y a torno). Estos fragmentos se individualizan con someras referencias y dibujos en las casillas correspondientes a los números 318 a 349 del Inventario.

El propio Bosch Gimpera anota el destino de estos materiales: la anforilla, el vaso teromorfo, la pata de mesa y alguna otra vasija o fragmento más vistoso, así como los más singulares objetos de metal enriquecieron las vitrinas del entonces Museo Municipal de Barcelona. En el actual Museo Arqueológico de esta ciudad pueden contemplarse en su mayoría, si bien las piezas depositadas en el Almacén, tras las muchas vicisitudes habidas, son de identificación más problemática.

\section{INTERPRETACION DEL RELLENO}

De la lectura del Diario se desprende que los trabajos se iniciaron en la esquina de una habitación semiexcavada en la roca con paredes de mamposteria apoyadas en un banco labrado en el propio terreno. Obviamente la bancada condicionaba la potencia de las capas, justificando así la diferencia de profundidad y espesor entre la base de las paredes (limitadas por la zona del banco) y el centro de la habitación, pródigo en hallazgos.

El hecho de que los fragmentos del vaso teromorfo aparecieran indistintamente en las capas 2 y 3 inválida la existencia de una estratigrafía auténtica y la deposición diacrónica de los distintos hallazgos, pues es fácil entender que la diferencia por capas o niveles no corresponde a estra- 


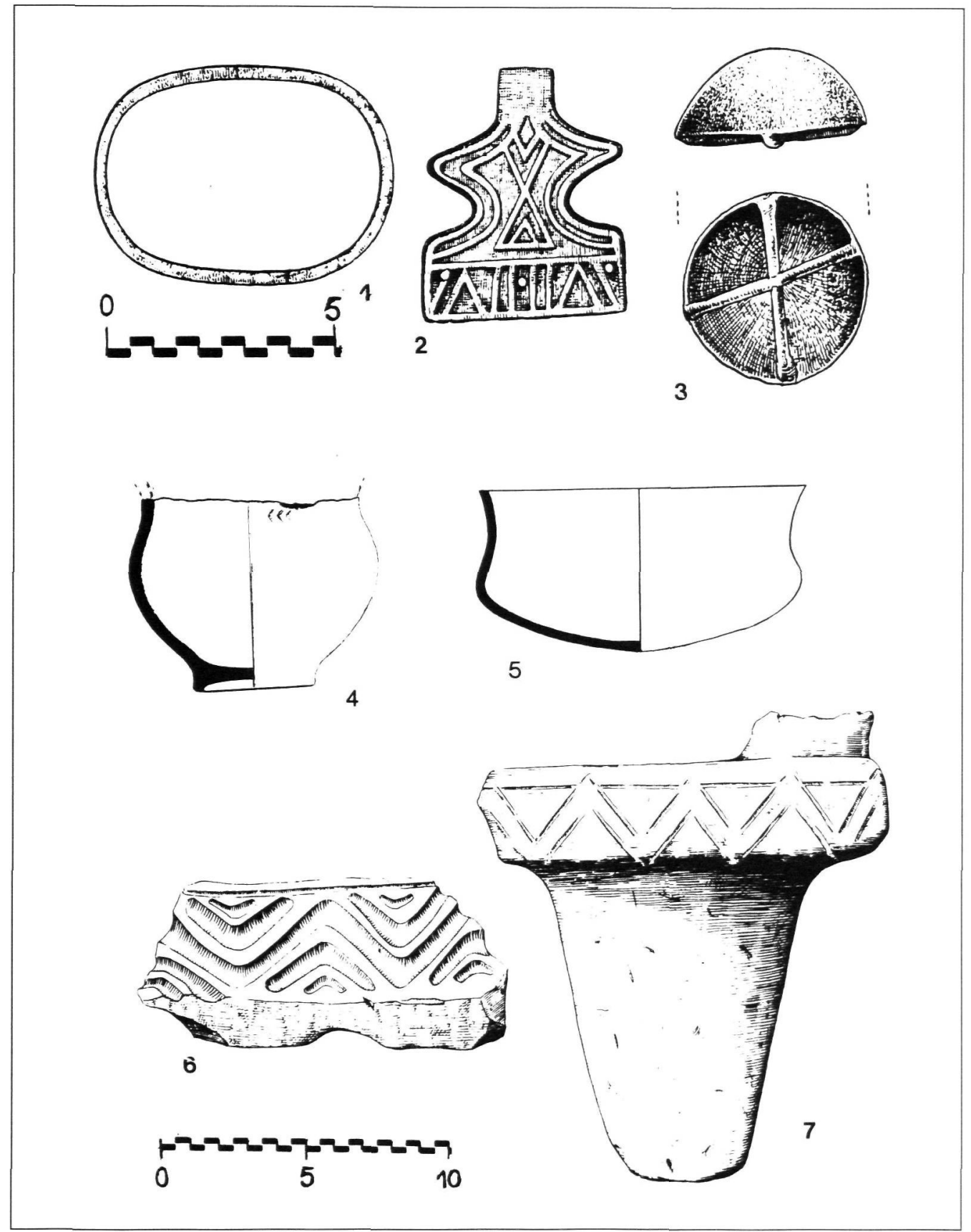

Figura 2. Materiales localizados en la Habitación 1 del poblado de Tossal Redó. 1 a 3: Objetos de metal; 4 y 5: Vasijas de cerámica; 6: Elemento de revestimiento; 7: Mesa fragmentada de barro. 


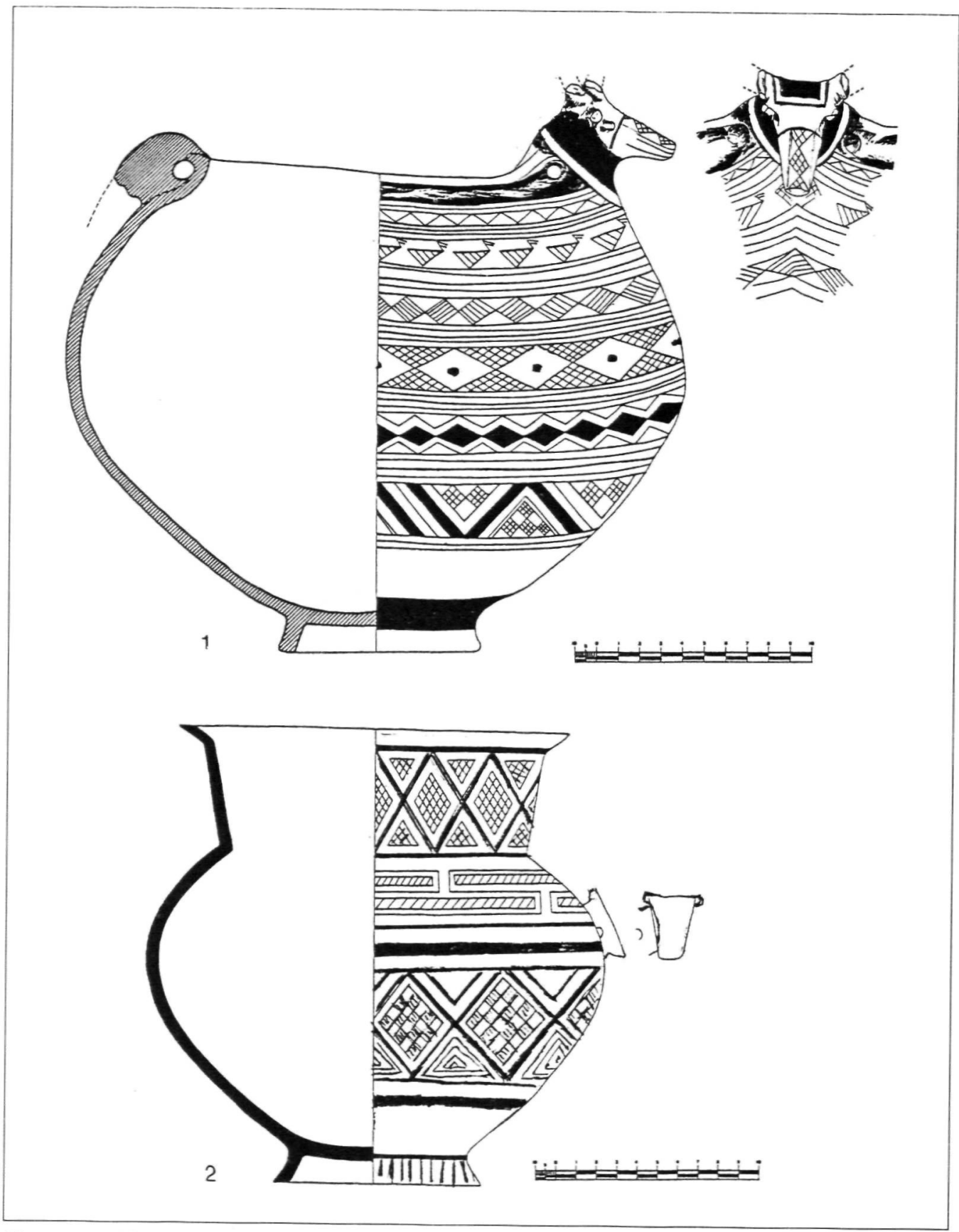

Figura 3.1 : Vaso pintado y con apéndices plásticos procedente de Tossal Redó. 2 : Vaso pintado y con cabecita bovina procedente del poblado de San Cristobal (Mazaleón, Teruel). 
tos sellados. La coloración de las tierras y su textura pueden explicarse como efecto del derrumbe de paredes y techumbre a consecuencia de la acción de un fuerte incendio, apreciado en las breves descripciones de Bosch y patente en algunos de los materiales conservados.

Entiendo que sobre el suelo de roca que conforma la capa 3, la más débil y menos uniforme y la más afectada por el fuego, (madera carbonizada, carbones y tierra quemada) se acumularon los residuos de la combustión de los materiales orgánicos (techumbre, postes...), presa fácil de las llamas; sobre ellos se superpondrían las piedras y adobes que recrecían los muros (capa 2). El desplome total de los restos abandonados y la incuria del tiempo serían responsables de la capa de "tierra vegetal llena de raíces" (Bosch, 1913/14, 829), en la cual, según el Diario, se recogió un vasito casi intacto.

Sobre el banco, en vasares o colgados de lo alto, estarían dispuestos parte de los recipientes (entre ellos el vaso con cabeza animal y la mesa de barro) que comienzan a aparecer en la capa 2. Aplastados por la caída de la techumbre, sus restos se esparcieron a distinta profundidad. Queda la duda de si la anforilla inventariada con el núm. 317 sufrió la misma suerte o si, como parece, estaba colocada sobre el suelo, guardando en su interior los objetos metálicos localizados entre las tierras de la capa más profunda, en donde se hallaron los framentos decorados de barro tosco.

Esto es, en síntesis, cuanto se desprende sobre las circunstancias y contexto del vaso teromorfo, pues la lectura del Diario no deja dudas acerca de la coetaneidad en el uso o amortización de todos los materiales localizados, al menos en las capas 2 y 3 .

La huella de un fuerte incendio y las características de las tierras de esta estancia 1, salvo excepciones que afectan a las zonas de mayor erosión, se constatan en otras habitaciones o casas del Poblado Grande, completamente excavado en la campaña de 1916. Los objetos exhumados, algunos muy conocidos por la bibliografía (especialmente las fíbulas), coinciden cronológicamente con la fecha estimada para los hallazgos más singulares de la Cámara 1 y es de interés señalar, aunque las publicaciones sean contradictorias, que la única mención del Diario sobre la existencia de cerámica a torno en el poblado Grande corresponde a los materiales registrados en la excavación de prueba.

\section{EL VASO TEROMORFO (LAM. I Y II Y FIG. 3, 1)}

\section{A. Descripción}

Tal y como se aprecia en el recipiente expuesto en el Museo de Barcelona, tempranamente restaurado por el Sr. Gandía, sus características responden a las especificadas por Bosch Gimpera en el diario de campo o en la posterior publicación (Bosh Gimpera 1913/14).

En efecto, la pasta es de cocción oxidante, muy compacta, y la superficie exterior, crema/rosada, está cuidada y bien pulida, intencionadamente preparada para recibir la decoración a pincel y realzar el juego bícromo por contraste entre el fondo claro y el colorante granate usado como pintura.

Forma: El cuerpo de la vasija, exagerdamente ancho y de silueta aquillada, es esferoide y apoya en corto pie hueco, ligeramente acampanado. La parte alta, de tendencia cerrada, es la zona más singular. Se distingue un corto cuello cilindroide de borde casi horizontal (unos 10 $\mathrm{mm}$. de anchura máxima) que rodea parcialmente la abertura elipsoidal de la boca. En los extremos del eje mayor el borde se atenua y sin solución de continuidad sirve de tránsito a los remates plásticos -cabeza y cola de bóvido- que caracterizan este recipiente. 


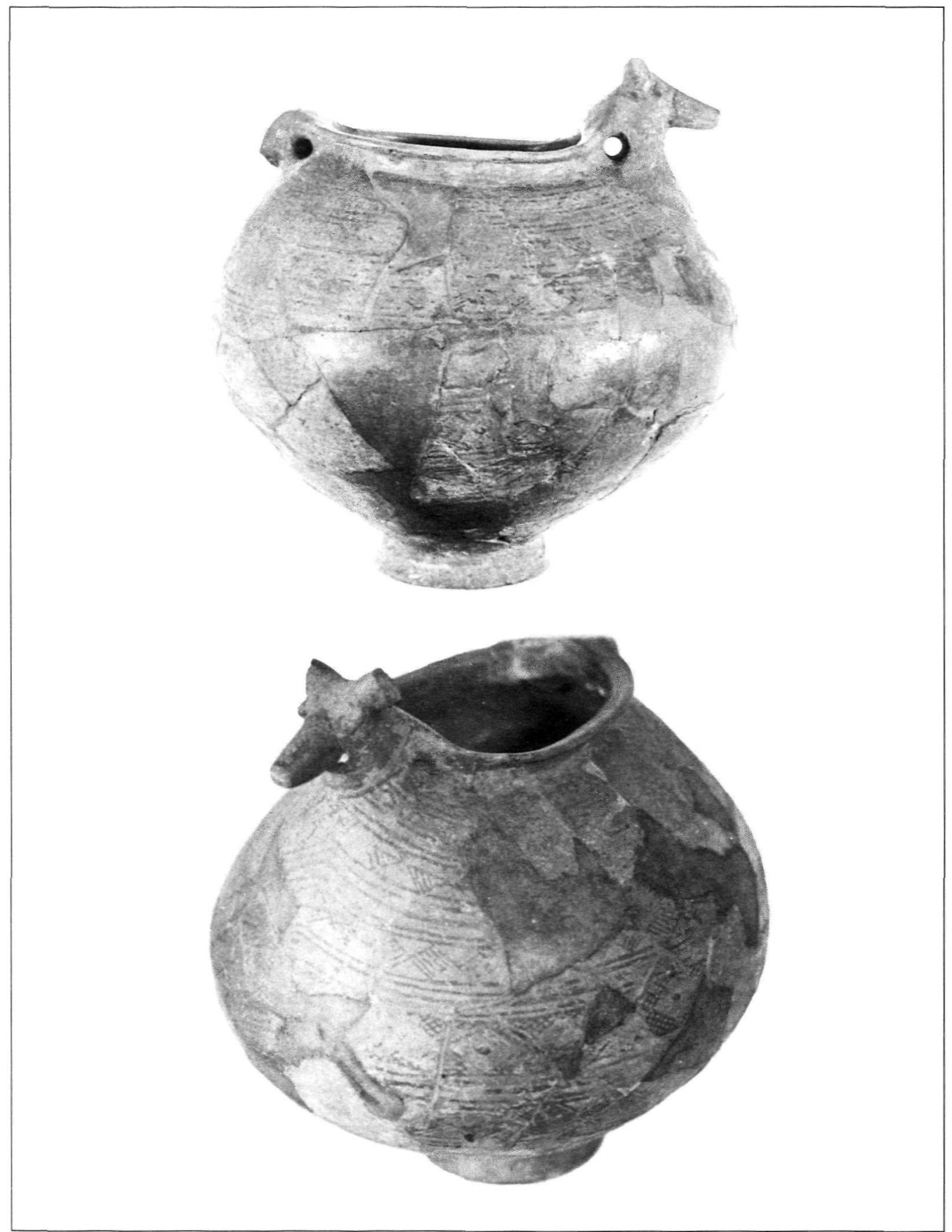

Lámina I. Vaso con apéndices plásticos. Tossal Redó. 
El prótomo, exento y a modo de espolón, consta de un cuello de cerviz arqueada, corta y robusta, en contraste con la ligereza de la cabecita de silueta muy simple y abocinada $(50 \mathrm{~mm}$. de longitud) en la que se han indicado los rasgos que identifican la especie animal: ojos, orejas y cornamenta de un toro. Los ojos parecen marcados por toscas incisiones mientras las orejas se conformaron mediante apéndices salientes, hoy incompletos al igual que los cuernos que coronan la testuz y que, a juzgar por la dirección y sección de la rotura, pudieron ostentar aspecto liriforme y cierto desarrollo. En la zona en que se une el protomo al cuello de la vasija se practicó una perforación horizontal (diámetro medio de unos $10 \mathrm{~mm}$.) que atraviesa por completo el grueso de la pared, convirtiendo el apéndice zoomorfo en una especie de asa. En la parte opuesta se representó la cola sobreelevada, de grosor decreciente y aspecto muy simple. Está parcialmente rota y el extremo desaparecido se prolongaría conectado a la pared del vaso. Aprovechando la protuberancia del apéndice caudal se perforó la zona en simetría con la cabeza. Un dato a remarcar es la intensa huella dejada por el fuego en este extremo y en la parte correpondiente del cuerpo.

Dimensiones: Altura mínima del recipiente (eje vertical desde el centro del pie a la boca): $230 \mathrm{~mm}$. Altura máxima hasta los apéndices corniformes fracturados: $280 \mathrm{~mm}$. (la base se eleva $15 \mathrm{~mm}$. y tiene $100 \mathrm{~mm}$. de diámetro máximo). Anchura máxima del cuerpo: $285 \mathrm{~mm}$. El orificio elipsoidal de la boca mide : 130 por $110 \mathrm{~mm}$. Desarrollo máximo del cuello: $10 \mathrm{~mm}$. Las paredes, aun de cierto grosor, son relativamente finas si se tiene en cuenta el tamaño de la pieza cuya capacidad se estima en unos seis litros y medio.

Como puede apreciarse, el vaso en su conjunto es más ancho que alto aunque, cuando los cuernos del protomo estuvieran completos, existiría un cierto equilibrio respecto a la altura total de la vasija; en este caso la silueta irregular remarcaría todavía más el aspecto aquillado de la parte correspondiente a la cabeza astada.

Decoración pintada: No se dispone de análisis de los pigmentos, pero es obvio que se empleó un colorante rojo-granate muy denso que se desprende con facilidad, sin duda porque el pulido superficial no favoreció la adherencia.

La pintura, aplicada con pincel y a mano alzada, se conserva desigualmente y el diseño acusa las lagunas de los fragmentos y la alteración sufrida. A trechos el color mantiene toda su consistencia mostrando claramente (en especial en la cenefa 4a. y en la testuz) un acusado relieve.

La técnica, que en términos franceses se denominaría a "la barbotine, es considerada en la bibliografía sobre este vaso como una aplicación "post cocción". No obstante, el efecto bícromo del exterior es comparable al de otras cerámicas mediterráneas en que la cocción de la pintura no se cuestiona. Ciertamente, el incendio detectado en el lugar del hallazgo pudo favorecer estos resultados, pero, tal y como se aprecia en las fotografías, la decoración está muy perdida en las zonas más afectadas por la intensidad de la combustión (cola y alguno sectores del cuerpo) (2).

La estética y organización del diseño ornamental tienen muy en cuenta el contraste de la pintura con la superficie de fondo y el juego de luz y sombras originado por la morfología de la pieza. Así se entiende la anchura y particularidad del friso inferior, el espacio en reserva sobre el pie y las bandas de pintura lisa que ciñen el estrangulamiento de la base y marcan la unidad cue-

(2).El hecho de que la pintura salte con facilidad obedece, por una parte, a la ausencia de engobe o preparación adecuada; por otra al desequilibrio físico entre la densidad y la adhesión, pues obviamente la tersura del soporte no favorecía la penetración de los pigmentos. 


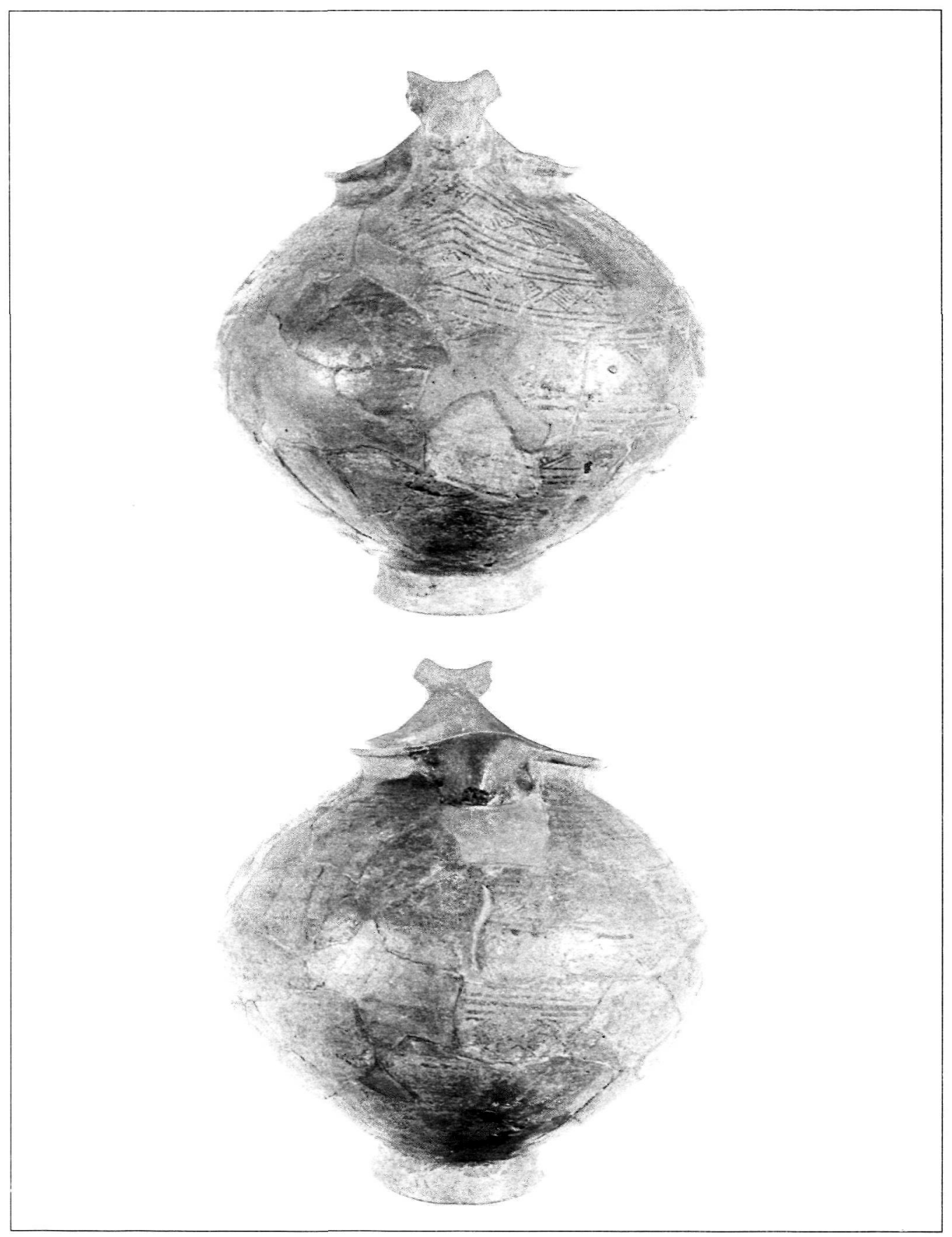

Lámina II. Detalles de los apéndices plásticos del vaso teromorfo de Tossal Redó. 
llo-borde desbordando, por una parte, en el apéndice de la cola, por otra, en el protomo animal delimitado por un collarín, libre de pintura. El campo restante, limitado arriba y abajo por tres filetes paralelos, está dividido en seis cenefas de temática y anchura desigual, separadas entre sí por cinco filetes cuyas líneas extremas enmarcan el encadenamiento reiterado del motivo que singulariza la individualidad de cada banda. Las diferentes franjas discurren paralelas circundando el vaso y se adaptan perfectamente a la arquitectura irregular del cuerpo; por ello en la parte superior (pecho teórico del bóvido) dibujan una inflexión angular que salva la disimetría de la zona alta y deliberadamente reclaman y fuerzan la visión hacia la cabeza de toro.

No me detengo en la descripción pormenorizada de cada banda pues la sintaxis decorativa se aprecia muy bien en la magnífica fotografía que ilustra la publicación del Profesor Bosch Gimpera (1914). Sin embargo, existen ligeras variantes respecto a los dibujos publicados (3). Estas rectificaciones corresponden:

1) A la cenefa de dientes de lobo con rayado oblicuo (2a. de la serie). Según mis observaciones (1987) los trazos dibujan una hilera de aves de cuerpo triangular con esquemática cabeza y privadas de patas. La figura es análoga a otras representaciones que, con diferentes técnicas, decoran distintas cerámicas del Valle del Ebro (Rodans y Royo, 1986, 384) y muy similar a las pintadas (ocasionalmente incisas) en algunos fragmentos del SO. de Andalucía (Buero, 1986, fig. 5) o en materiales orientalizantes del SE. (M. Pellicer, 1984, 220).

2) En los laterales del protomo zoomorfo (detalle de Fig. 3,1) se aprecian una serie de líneas divergentes que confluyen en la boca y, en la parte alta, entre los cuernos, se pintó una especie de recuadro a modo de almohadilla; además, una cadena de rombos discurre por el frente y resuelve el tránsito a la zona circular del "morro", sin rellenar por completo el hocico.

\section{B. Estudio analítico}

La vasija del Tossal Redó, pese a su anómalo cuerpo, carece del asa y del elemento vertedor que caracteriza al "askos", por otra parte la silueta no modela en todos los detalles la figura animal, por tanto no es plenamente zoomorfa. Sin embargo, tal y como su calificativo expresa, se sitúa en línea conceptual con los caprichosos recipientes que de alguna manera evocan la imagen animal. Maximova (1927) unificó bajo el nombre genérico de vasos plásticos diversas modalidades alfareras (askos, kernos...) que comparten la función orgánica de recipiente/estatua. Esta denominación es válida, pero, teniendo en cuenta que la estética de los elementos animales no suponen detrimento ni condicionan la funcionalidad y la forma general se sigue conservando, la clasificación como vaso con apéndices zoomorfos me parece más precisa y menos ambigua.

En la Península Ibérica, vasos plásticos, siempre excepcionales, se documentan en ajuares megalíticos y es bien conocido el ornitomorfo procedente del sepulcro de La Zarcita en Huelva (Cerdán y Leisner, 1952, 116-117 y Lám. XXXIV 1 y XXXV 1), pero debe reconocerse que no existe continuidad en el substrato indígena y sólo avanzado el primer milenio hallaremos, tanto

(3) La reciente visita me permitió observar nuevamente los detalles, rectificando ligeramente algunas incorrecciones, entre ellas la decoración de la cabeza y la modalidad de yuxtaposición de las aves. Al tratarse de unos fragmentos enengrecidos de delicada decoración, restaurados con técnicas antiguas, no resulta fácil seguir y delimitar las líneas. Esta es la razón de las pequeñas diferencias respecto al dibujo que publiqué 1987 y que ilustra la portada de la obra de Sigrid Werner, de reciente aparición. 
en áreas del interior como ambientes mediterráneos, objetos de alfarería o metal con protuberancias zoomorfas. Algunos de ellos se vinculan claramente a tradiciones continentales (recordemos los morillos e incluso el vaso-pájaro de la tumba de la necrópolis de Las Cogotas en Avila), pero la mayor fortuna de esta modalidad de remates es deudora de préstamos orientales.

De las vasijas hispano-francesas netamente ornitomorfas se ocuparon en 1966 J.J. Jully y S. Nordström. Hoy el repertorio es susceptible de aumento (para España: Broncano, 1989, 212216) y cabría insistir en modelos y en las cuestiones de antecedentes y dispersión geográfica, pero es evidente que ni éste ni otro tipo de vasos plásticos cuenta con suficientes argumentos como para invocar un origen autóctono.

Por ello llama la atención que aproximadamente por las mismas fechas y dentro de contextos culturales muy próximos existiera cierto favor por los vasos con apéndices zoomorfos. Me refiero en concreto a tres vasijas más:

-Al vecino poblado de San Cristóbal, en Mazaleón, pertenece un recipiente de cuello cilíndrico y pie acampanado con cabecita muy plana, astada y perforada, colacada en el centro (Fig. $3,2)$. La superficie clara lleva también cenefas de diseños geométricas pintadas en rojo (Atrián,1961, Lám. VI).

-En el ajuar de la tumba núm. 162 de la necrópolis francesa de Grand Bassin I en Cayla de Mailhac (Taffanel, 1962) se depositó un vaso con cuello acampanado, pedestal cúbico fenestrado y protomo bovino en el hombro, afectado en este lateral por un perfil aquillado, remedando el cuerpo de un ave (Fig. 4, 1).

-También es digno de mención, aunque el animal elegido sea diferente, un olvidado vaso hallado en Ampurias (necrópolis de Portitxol, (García y Bellido, 1948, II, 152, Núm. 26 y Lám. LXXI) de perfil aquillado y silueta ornitomorfa con pie acampanado y perforado; la boca, a semejanza del vaso del Tossal, remata en un airoso cuello de ave y su correspondiente cola y, además, se singulariza por incluir en el borde un pequeño vasito a manera de un kernos. La manufactura de esta vasija es claramente indígena y morfológicamente difiere de los askoi zoomorfos localizados en el complejo ampuritano catalogados en la misma obra de García y Bellido como "vasos de estilos orientales."

Los tres vasos mencionados son indígenas y también están fabricados a mano. El problema está en dilucidar si la inspiración y el gusto por este tipo de objetos parte, como se viene considerando tradicionalmente, de influjos o contactos continentales (teoría céltica o hallsttática) o si los precedentes son orientales y, en este último caso, si la vía proviene del orientalizante español (como postula Pellicer) o por otros mecanismos. Desgraciadamente, la ausencia de paralelos exactos y, paradójicamente, la multiplicidad y dipersión de afinidades, obliga a comentar las hipótesis formuladas sobre el origen del modelo inspirador. En la búsqueda, para no valorar paralelos engañosos, he atendido a las siguientes variables, consustanciales a la entidad de la vasija del Tossal Redó :

a) Morfología primaria del recipiente.

b) Perforación y caracteres de los elementos plásticos (cabeza y cola), no adaptados a la función vertedora.

c) Asociación bóvido (o animal cornípeta)/ave.

d) Sintaxis y temática de la decoración pintada.

Antes de entrar en la discusión sobre elementos exógenos en la zona es obligado analizar el substrato indígena.

La forma, si hacemos abstracción del abombamiento lateral, se reduce a un cuerpo globuloso de borde vuelto con dos pequeñas asas y pie hueco de escasa altura. Precisamente este elemento 
(común a los citados ejemplos franco-hispanos con apéndices zoomorfos) se vincula a influjos transpirenicos y, en cierto modo, sirve de indicador temporal. Excepcional resulta el cuerpo globuloso, más ancho que alto, sin apenas cuello, pues aun cuando en el poblado de San Cristóbal de Mazaleón un vaso no decorado y carente de asas (Atrián, Fig. 3) responde a este esquema, la forma en su conjunto no cuenta con tradición local (4).

Respecto a la decoración pintada y los motivos el problema es más complejo. En el poblado de San Cristóbal se han recuperado testimonios de seis vasijas a mano con decoración pintada y Bosch Gimpera dio a conocer una serie de fragmentos procedentes de una cista próxima (1913/14, 823 y Lám. a color) y menciona, además, otros fragmentos procedentes del poblado y de la necrópolis $(1920,646-647)$, lo que supone, por la variedad morfológica, técnica y cromática (rojo, amarillo-marrón y violáceo y superficie sobre fondos diferentes) un crecido lote, posible testimonio de un artesanado afincado en la zona y versado en la cerámica de color (otros fragmentos pintados se hallan en áreas relativamente próximas: poblados de Cabezo de Moleón y de Palermo en Caspe, Zaragoza, y cista del Cascarujo en Alcañiz, Teruel).

Aguas arriba del Ebro, el importante poblado de Cortes de Navarra testifica la presencia de otro centro de pintura vascular indígena, con técnica y patrones diferentes a cuanto se halla en Aragón.

En general, el estilo de Tossal Redó recuerda la cerámica "tipo Carambolo" (Almagro, 1977, 120-125) o tartésica. Incluso la hilera de aves ápodas encuentra paralelos en un fragmento de Valencina de la Concepción (Sevilla), pero difiere la estructura compositiva, la temática y la forma. En el estado actual de los hallazgos (muy fragmentados), es difícil rellenar vacíos y lagunas, y tampoco queda clara la dependencia respecto a los dispersos fragmentos con pintura roja geométrica sobre fondos claros (a mano o a torno) localizados en ambientes más o menos relacionados con los influjos coloniales (Murillo, 1989; Werner, 1990). El simple contraste entre Mazaleón y Tossal Redó, geográfica y culturalmente tan próximos, evidencia los localismos y la multiplicidad de talleres, si bien el repertorio, aunque varía la organización, comparte la afición por los temas geométricos encadenados. A este respecto es destacable la continuidad de viejos motivos propios del campaniforme y sobre todo la popularidad que alcanza entre la cerámica incisa del valle del Ebro la serie de rombos encadenados con rayado oblicuo en cadencias opuestas (cenefa 3 del vaso). La organización decorativa varía, pero existe afinidad temática en técnica incisa e incluso excisa, advertida en su momento por el propio Bosch Gimpera, por Cabré al estudiar las cerámicas del Roquizal del Rullo en Fabara (Zaragoza), por Martínez Santa-Olalla y otros autores. Importa destacar la tendencia a dejar libre de decoración la parte baja de la vasija (caso del Roquizal del Rullo) y el hecho de que sea en la técnica excisa, cuyo cénit se centra

(4) Este tipo de pie aparece en el Nordeste paralelamente al desarrollo del Bronce Final IIIB de Languedoc (Mailhac I), etapa en que los influjos protovillanovianos e itálicos en general no son desdeñables. En la necrópolis de Agullana (Fase I), el vaso de la tumba 53, tipo I (Palol, 1958, Fig. 48 y Núm. 52 de la tabla VI) recuerda esta forma cuyas variantes se multiplican durante la etapa que podemos considerar Hierro I. Las citas serían tediosas, basta mencionar el considerable número de vasos de cierto tamaño y pie desarrollado tan abundantes en poblados vecinos como el de Escodines Altas (Bosch Gimpera, 1920, Fig. 486) y en el propio Tossal Redó. Sólo en sincronía a la fecha que se puede asignar al vaso teromorfo comienzan a aparecer en distintos ambientes vasos sin asas de cuerpos esferoides, escaso cuello y corto pie, incluyendo zonas más meridionales, caso del Cerro del Macareno en Sevilla. 
entre finales del siglo VIII y VII (Alvarez y Pérez Arrondo, 1987, Fig. 46, 3.1 y 4.2) donde hallemos los temas más excepcionales, como la cenefa de pájaros esquemáticos o la fila de rombos plenos entre angulaciones (cenefas 2 y 5 del vaso), mientras no existe parangón para la gran banda inferior de angulaciones y triángulos con dameros enrejillados.

No deja de extrañar la escasa incidencia de estos temas en Cataluña, área en donde está bien documentada la línea de meandros, uno de los motivos del vaso con apéndice zoomorfo de Mazaleón. Precisamente, en la cerámica (y en el metal) de diversos círculos del Bronce Final y Primer Hierro del Centro y Sur de Francia, se repiten los mismos diseños geométricos, bien estudiados en técnicas de incisión, excisión y grafito, cuyos pararalelos remiten fundamentalmente al Norte de Italia, Alsacia, Suiza y Baviera.

Afortunadamente los ejemplos de vasijas francesas con decoración geométrica pintada (s. VII y VI) -tradicionalmente consideradas "pseudo-jonias"- son cada día más abundantes y más dilatada su repartición (Lagrand, 1987). No obstante, al igual que ocurre con la larga vida y diversidad de las cerámicas pintadas geométricas de los contextos indígenas españoles, llama la atención la perduración de un linealismo teóricamente trasnochado que recuerda la cerámica de Dipylon, sin que, pese a las afinidades técnicas (pintura roja sobre engobe claro) y temáticas (rombos, triángulos, dameros...), se evidencie claramente el foco trasmisor ni la constatación de hallazgos exógenes que clarifiquen los hipotéticos modelos. Aves, más o menos esquemáticas, se pintaron en las cerámicas "pseudo-jonias" del oppidum de Vix (Côte-d'Or en Borgoña), asociadas, en un confuso contexto, a "bucchero nero" etrusco y cerámicas griegas de figuras negras (Joffroy, 1976, Fig. 4). En este caso, como en Tossal Redó, la decoración zoomorfa es excepcional puesto que la pintura roja, "a la barbotina" sobre engobe crema, insiste en franjas horizontales o verticales a base de motivos geométricos lineales cuya organización es comparable (no idéntica) al conjunto de pintura vascular de Mazaleón, coincidiendo incluso en la aplicación de la pintura a vasijas en forma de copas. En realidad, los precedentes y trayectoria histórica de la decoración pintada geométrica o la esquematización, de ave, al igual que los apéndices zoomorfos, se pierden en una enmarañada red de viejas y renovadas convergencias que apuntan hacia estímulos orientales. Pero esta no es la única vía posible, pues no se debe olvidar la antigüedad y tradición de los vasos plásticos en las regiones transdanubianas y en los Cárpatos, así como la trascendencia que tiene en toda Europa central el tema del ave y el vigor que alcanzan en ciertos ambientes los diseños geométricos y la cerámica pintada.

\section{La cuestión orientalizante}

En líneas generales, la inspiración oriental es común para la mayoría de vasos plásticos circummediterráneos. En los teromorfos se advierte la elección prioritaria de la imagen de un ave y de cuadrupedos astados con preferencia del toro sobre el ciervo o sobre el carnero, aunque no se desdeñen otros animales o se sugiera en el conjunto la imagen de una barco o de una temática mucho más compleja. Desde el tercer milenio aparecen en Egipto, Anatolia y Grecia prehelénica continental e insular, destacando la fantasía de la alfarería del bronce chipriota, que, sin duda, contribuyó a enriquecer y fomentar el gusto por los formas y apliques zoomorfos (en especial toros).

A partir del s. VIII a. de C. los vasos plásticos son corrientes en ambientes minorasiáticos y fenicios, con especial incidencia en las islas del Egeo (Creta, Rodas. y la propia Chipre: Buchholz y Karageorghis, 1973, passim y Schweitzer,1971), responsables de su difusión hacia occidente (Cintas 1970. vol. I, 414,.Láms XI, XII y XIV). En esta corriente se insertan, entre otros, 
los magníficos jarros de bronce con cabezas en relieve hallados en España, así como el kernos anular de Mérida, pintado y con un protomo de ciervo con cabecita troncónica como la del Tosssal. Son claros los paralelos con Chipre y Rodas (Buccholz y Karageorghis, 1973, 448-50), aunque J.M. Blázquez (1975, 75 y 76, nota 12) se inclina por un origen en la isla de Samos.

Pese a estos ejemplos, la cerámica plástica registrada en el orientalizante español no aboga por una popularidad paragonable a la alcanzada en ambientes egeos, cipro-fenicios o púnicos. Los hallazgos, reducidos meramente a apéndices o pequeños fragmentos, son poco elocuentes para el tema que nos ocupa: un prótomo de ave de un posible askos procede de la factoría fenicia de Toscanos (Schubart y Maas-Lindemann, 1984,138-139, Fig. 20); a esta misma categoría de recipientes se atribuye otro fragmento localizado junto a materiales antiguos de la Isla de Ibiza, planteando, según Gómez Bellard (1990, 133) "un auténtico dilema." Al poblado alicantino de Peña Negra I en Crevillente se adscribe una cabecita pintada de carnero (González Prats, 1983, 78. Fig. 20), ignorando si se trata de una figurilla o de un vaso. El mismo problema presenta el bucráneo de terracota localizado en el viejo santuario de Cástulo (Blázquez y Valiente, 1981, 207 y Lám. XXVI) y las toscas cabezas de toro que ornamentan algunos recipientes a mano del Sur de Portugal, fechados en el s. VI a. C. (Beirao, 1986, 98 y Fig. 15) no admiten correspondencia. Para todos los ejemplos se apunta la analogía con modelos chipriotas porque, efectivamente, Chipre cuenta con un repertorio de vasos plásticos amplio, variado y de larga tradición, además de sus comprobadas relaciones con el mundo fenicio.

A este reducido elenco hay que unir, como fruto del influjo cartaginés, la serie de vasos plásticos de Ibiza (Rodero, 1980, 127-129) y alguno de los de Ampurias, así como los que aparecen en la cultura ibérica, evidentemente más tardíos que el vaso del Tossal Redó.

Desde el punto de vista morfológico las afinidades más estrechas y reiteradas, nunca identidad, se hallan tanto en vasos cerámicos como en recipientes de metal reiteradamente documentados en dos áreas principales: Península Itálica y territorios de Asia Occidental, incluyendo las islas del Egeo. El parentesco morfológico se puede rastrear ya en los calderos de Urartu, adornados con protomos de bóvidos y otras figuraciones, actúen o no de asas, y, curiosamente, en los relieves neohititas de los ortostatos de Malarya (Arslantepe) fechados en los inicios del primer milenio, los recipicientes utilizados en las libaciones reales son el paralelo formal más exacto al vaso que nos ocupa (Bittel, 1976, Fig. 276 y 278), pese a que no se distinga si las asas sobreelevadas son zoomorfas.

Este tipo de vasija ancha con dos asas dispuestas junto al borde se corresponde a la forma BII b-1 de Cintas (1970, 347-350: marmitas como la procedente de Lapithos) y, en cualquier caso, silueta y capacidad del vaso teriomorfo del Tossal guardan equivalencia con numerosos recipientes utilizados en el mundo griego y oriental para el servicio de la bebida, sean de tipo crateroide, dinos, lebetes... e incluso stamnos. Teóricamente es factible la imitación de la forma y la llegada de producciones prefoceas pero, de momento, la presencia de este tipo de vasijas es más latente que real.

Si centramos nuestra atención en la decoración geométrica, ha de concluirse que tanto la técnica, el recurso de la bicromía, la temática y la organización son propios del geométrico griego (Coldstrean, 1977, passim). Justamente entre el repertorio tardo-geométrico de las cerámicas del cementerio de Fortetsa en la isla de Creta he hallado la mayor afinidad de motivos, así como la presencia de askoi con protomo y cola zoomorfa (Brock, 1957, Lám. 23, 354; tema 4, j = triángulo rayado; hilera $5 \mathrm{v}=4 \mathrm{a}$. cenefa vaso Tossal Redó: $5 \mathrm{ar}=5 \mathrm{a}$. cenefa: $4 \mathrm{ak}=6 \mathrm{a}$. cenefa...). El motivo de esta última cenefa triángulo relleno con rombos- no es desconocido en Chipre, pero, 
combinado con las franjas de zig-zags es, según señala Schweitzer (1971, 84, Fig. 48), característico de las cerámicas del geométrico tardío de Rodas (segunda mitad del siglo VIII: cementerios de Exochi y Camiros). En cualquier caso y sin contar con un buen lote de materiales que contrasten claramente las analogías, las referencias puntuales al repertorio geométrico de una región o isla determinada no pasan de banales porque no podemos enlazar nuestra ornamentación geométrica pintada con los modelos inspiradores.

El problema está en la parquedad de precedentes y a este respecto debe indicarse que los fragmentos con decoración de grandes triángulos con rombos en damero rellenos por paralelas, recuperados en el asentamiento fenicio de Morro de la Mezquitilla (Fase BII-IV) citados por M. Pellicer como argumento del carácter "orientalizante" del vaso teromorfo, están ejecutados en técnica incisa y a mano y, según Schubart, (1979, 202-203, Fig. 15, g y Lám. VII) forman parte del componente del Hierro Antiguo índigena (asociado a cerámica excisa).

Así pues, el panorama sobre los vasos plásticos no se clarifica ni refuerza con la temática y organización de la decoración geométrica; los testimonios sobre posibles modelos alóctonos llegados a la Península son todavía muy débiles (Cabrera, 1981 y 1986) y trayectoria y origen son discutibles y ramificados, aparte de la no coincidencia con el área del Ebro (5).

Mayor ambigüedad de préstamos y corrientes aporta la cenefa de aves. Origen del tema, disposición en hilera y tendencia a simplicar la figura son muy antiguos. Aves pintadas existen en cerámicas anatólicas del $\mathrm{II}^{\circ}$. milenio a. C. y el yacimiento de Tepé Hissar en Irán también provee numerosos ejemplos de este motivo que, por otra parte, inciso o estampillado, es habitual en la vajilla kasita, al igual que la decoración plástica (Ayoub, 1982, 24, 25...). Como opina Cintas (1970, 403-405 y 410-416, Lám. XXXII) la larga tradición mesopotámica se incorpora a la "koiné" sirio-palestina y los ejemplos se suceden ininterrumpidamente desde el Bronce Medio hasta llegar al repertorio oriental estrictamente geométrico. A partir de este momento, entre 1000 y 800 a. C., con anterioridad a los "bird-bowls" y con notables particularismos en Creta, asistimos a una expansión ramificada, siguiendo un camino paralelo a la decoración lineal y subgeométrica.

En el sur de España se han localizado algunas importaciones con decoración de pájaros en Toscanos y Huelva, cuyos caracteres remiten a ambientes del Geométrico Final de Eubea, Chipre... e iricluso Italia (Cabrera, 1986, 575, Fig. 1) y en un huevo de avestruz de la necrópolis fenicia del cerro de San Cristóbal (Almuñecar, Málaga) se pintó un pájaro, esquemático (motivo que también aparece en otro huevo de Vulci). Estas piezas, son, por ahora, los testimonios exógenos más antiguos (fines s. VIII - inicios VII) y posibles precedentes de las imágenes de pájaro, más o menos naturalista o geométrico, con o sin patas, documentadas, tal y como se ha dicho, en las cerámicas pintadas indígenas del Sur y Sudeste, de precoz aparición, o en las decoradas del Valle del Ebro, área en la que también se localizan sencillas figurillas de pájaro en barro o metal, idénticas a las transpirenicas (p. e. en San Cristóbal de Mazaleón). En Francia, pequeñas aves ornamentan la base del "thymiaterion" languedociense de la necrópolis de Les Peyros en Couffoulens, tan semejante al ejemplar de Calaceite (Lucas, 1982) y, además de las fábulas ornito-

(5) En este sentido debe valorarse el excepcional hallazgo de la estela de Luna y las consideraciones al repecto de M. Bendala (1977) quien me sugiere la posibilidad de que el vaso pueda tener mayor antigüedad. 
morfas, cabe añadir que las aves, sólas o en hilera, no son infrecuentes en adornos personales relacionables con prestamos hallstátticos (Lámina de oro de Crevillente, joyas castreñas de incierta cronología.....).

Efectivamente, en sincronía con el trascurso del Hierro I, la Europa continental, siguiendo tradiciones que se remontan al Bronce de C.U., es pródiga en adornos ornitomorfos (aves aisladas, en hilera, afrontadas, opuestas...) sea en figurillas, colgantes, fábulas, cinturones, petos y en todo tipo de recipiente, siendo norma la imagen ápoda (Kossack, 1954, passim, mapas 20 y 21) aunque el dibujo en cerámica, siempre muy esquemático (cuerpo triangular o en rombo: Dobiat, 1982, Fig. 21), puede adoptar, a imitación de las vasijas-sonajero, base triangular o dos cortas patas (raramente una).

En resumen, la vía oriental es factible y en ella confluyen fenicios y griegos. La dispersión de paralelos dentro de la Península y la presencia cada vez más acusada de materiales fenicios en el Noreste son argumento razonable en favor de una inspiración emanada desde los ambientes de la costa meridional. Chipre, a través de los fenicios, sería el origen común con más posibilidades e incluso los vasos plásticos en forma de barca, proa con prótomo astado, aves, línẹas de zig-zags etc. podrían invocarse como antecedente. De momento faltan materiales que ratifiquen en exclusiva la validez de esta explicación y su extensión a los vasos con apéndices bovinos localizados a uno y otro lado de los Pirineos. Respecto a la acción de los influjos griegos, más plausible para estas regiones, los argumentos tampoco son del todo convincentes por insuficiencia de prototipos atribuibles a las islas o la Grecia Oriental con anterioridad al impacto de Marsella o Ampurias (Rouillard, 1978). No se puede descartar la aparición de nuevos hallazgos que verifiquen viejas teorías sobre precedentes prefoceos, pero es obvio que está lejos de zanjarse la cuestión. Por eso, llegados a este punto, la teoría de que el vaso teromorfo de Calaceite responda exclusivamente a estímulos o imitaciones venidos directamente desde oriente o desde las colonias fenicias del Sur, no queda, a mi juicio, suficientemente afianzada, sobre todo porque la organización y madurez de la decoración pintada y de la morfología exigen un avezado técnico que conozca en profundidad los modelos copiados. La hipótesis de una inspiración en las cerámicas incisas/excisas e incluso en tejidos podría ser válida para las cenefas, pero la morfología del vaso y la peculiaridad de los apéndices, invalidan "a priori" esta conjetura.

\section{La raigambre hallsttática}

Para mayor objetividad, sea brevemente, es obligado repasar la cuestión tradicional de la relación hallsttática. El territorio extendido de los Cárpatos a los Alpes cuenta con una variada y numerosa gama de vasos plásticos que remonta al Calcolítico. La serie más antigua y numerosa corresponde a siluetas ornitomorfas (Kóvacs, 1972) pero la mayor incidencia y homogeneidad se halla en la gama de "Stierprotomengefsse" ornamentada con apliques en forma de cabezas de toro o grifo (Fekete, 1985) en sincronía con el avance del Hallstatt C (s. VII) hasta entrado el s. VI (Weiss, 1979). En esta serie es normal la presencia de dos o más cabezas (nunca la cola) y, de acuerdo a la esbeltez del prótomo, se diferencian netamente dos modalidades: la que afecta a largos cuellos que arrancan de los hombros (identificable con los conocidos vasos de Gemeinlebarn en Austria : Fig. 4, 2) y la que agrupa protomos más cortos de cerviz cóncava y papada convexa situados en el cuerpo (por ejemplo, la urna de Sütto en Hungría : Fig. 4, 4). En unos y otros la cabeza es achatada o se ensancha hacia el morro difiriendo del ejemplar español, más próxima a modelos chipriotas. 

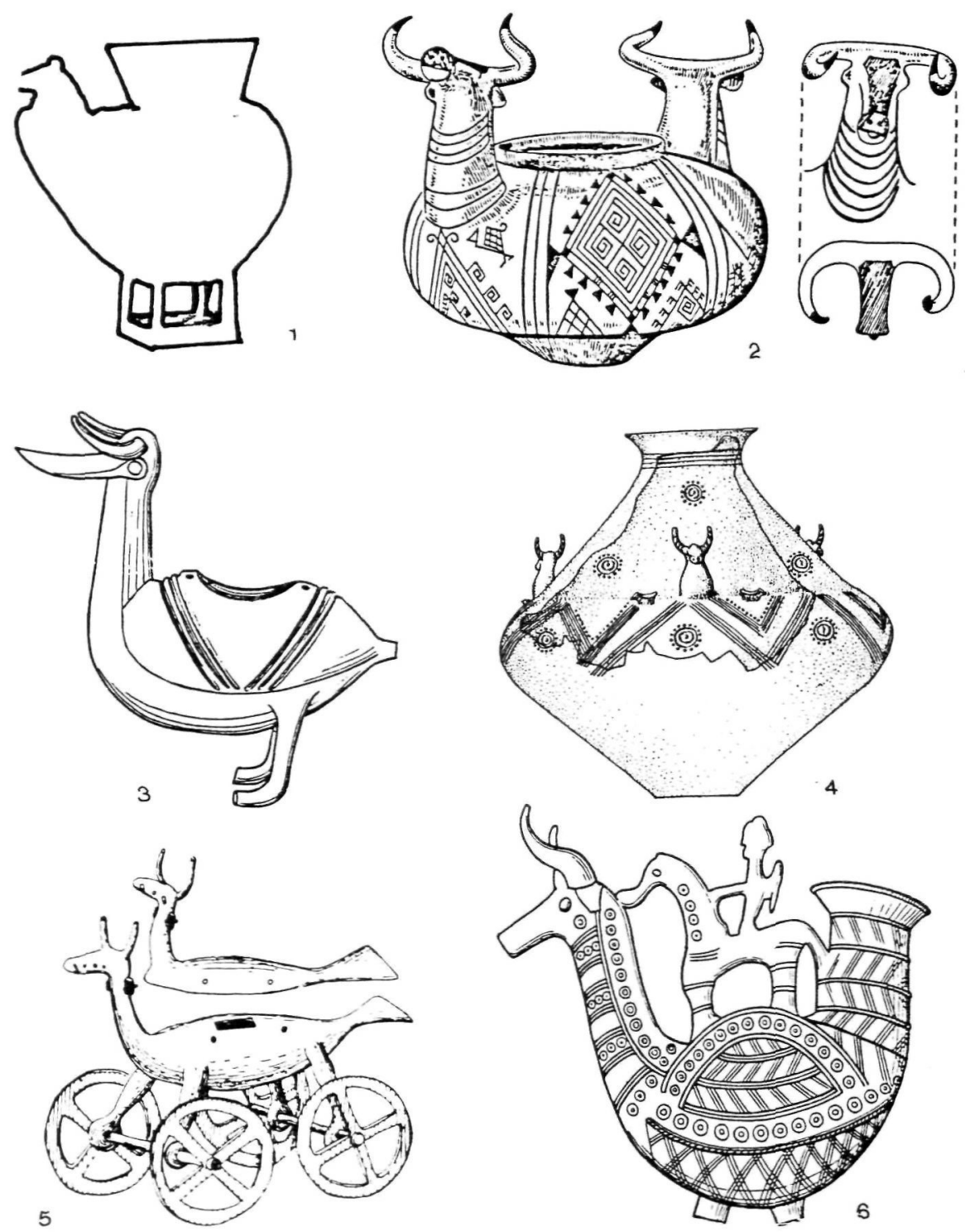

Figura 4.1: Vaso con cabecita bovina procedente de la necrópolis de Grand Bassin I (Cayla). 2: Vasija con cabezas de toro procedente del Túmulo 1 de Gemeinlebarn (Austria). Observese la figura de pájaro debajo de la cabeza astada. 3: Vasija metálica en forma de pájaro corniforme. Cic arovce (Checoslovaquia). 4: Urna decorada con prótomos bovinos y aves. Cementerio de Shütö (Hungría). 5: Carro cultual en forma de ave astada. Necrópolis de Monterozzi (Tarquinia). 6: Askos con cuerpo de ave y cabeza de toro. Necrópolis Benacci Bolonia). (Sin escala). 
En los ambientes del Hallstatt $\mathrm{C}$ las vasijas son globulosas, carecen de asas y no llevan pie hueco; el cuello, aun con labio horizontal, adopta forma de embudo y los hombros son muy destacados. No obstante existen excepciones en algunos yacimientos de Checoslovaquia y en la sítula austríaca de Kuffarn (Lucke y Frey, 1962, Lám. 65, 1) se representó un recipiente de este tipo con asa de cesta, posible imitación de ejemplares metálicos.

La decoración pintada geométrica de estas áreas, normalmente combinando pigmentos rojos y grafito, no se ajusta a la teoría ni a la sintaxis del ejemplar de Tossal Redó aunque en la temática (cenefas a base de meandros enteros o cortados, bandas metopadas y grandes triángulos o rombos con complejos apéndices angulares...) existan, aisladamente, ciertas concomitancias, siendo de valorar el gusto por grandes triángulos cuyo interior se compartimenta mediante dameros diagonales alternativamente enrejillados (última cenefa del vaso del Tossal Redó). Hay coincidencia en el recurso de dejar libre de decoración la parte inferior del cuerpo globuloso, ópticamente la menos visible. También debe reconocerse cierta analogía cromática y la reiteración de algunos motivos en la cerámica pintada del "oppidum" alemán de Heuneburg, de controvertido y enigmático origen (Dämmer, 1978).

Aparte de estas convergencias, existe afinidad temática con las cerámicas incisas ( $\mathrm{y}$ a la ruedecilla) del Norte de Baviera, bien evidentes en el yacimiento de Schirndorf, tanto en la sintaxis y ritmo como en la presencia de la imagen del ave con cuerpo triangular relleno de rombos en damero (Torbrügge, 1979 y Venze, 1980).

Fekete (1985) al estudiar varios ejemplos de vasijas con protomos zoomorfos procedentes de la necrópolis tumular de Vakeresztes (Hungría), insiste, como ya hizo en 1982, en las relaciones con Italia (etruscos y cultura de Este), pero, como otros muchos investigadores (p.e. Dobiat, 1982, 314) reconoce el peso global de las cerámicas del Egeo, especialmente de Rodas, así como los innegables contactos con la región de Frigia y el papel que pudo jugar en estas trasmisiones el área balcánica y la zona del Mar Negro.

Por otra parte, recordemos lo ya dicho para el tema del ave, tan arraigado y de tanta trascendecia simbólica, funcionando independientemente del modelo oriental. Es más, resulta característica la asociación en un mismo recipiente de imágenes de bóvido y aves: en la urna de Sütto las cabezas de toro alternan con figurillas plásticas de aves (Fig. 4,4); en una urna del túmulos 1 de Gemeinlebarn se dibujó, debajo de la cabeza astada, un pequeño pájaro (Fig. 4,2) y otra, de la misma necrópolis, tenía en el borde más de 30 orificios para colocar otros tantos pájaros (Kromer, 1958,).

Diversos autores, incluyendo a Hencken y Kossack, han puesto especial atención en esta dualidad de animales y en el área de su distribución. La asociación, según Kóvacs (1972 y 1980) es muy antigua y arranca del área oltina de Rumania y de la llanura cárpata. La urna de Törtel, datada en el s. XV a. C. y localizada en un enterramiento de la cultura cárpata de Vatya, tiene forma ornitomorfa y lleva dos orificios encima de los ojos para insertar unos cuernos, hoy perdidos, de materia orgánica. El extraño conjunto, aun careciendo de patas, es un puro remedo del recipiente metálico de Cicarovce que representa con gran naturalismo un híbrido pájaro de largos cuernos (Fig. 4, 3).

No existe un lazo directo entre los ejemplos más antiguos y las asociaciones protomos de toro/aves. Aun así, no se puede negar un trasfondo común de ideas o una relación genética que arranca del Bronce Medio de los Cárpatos, presumiblemente difundida por los C.U., desbordando en su trayectoria al marco alpino e italiano, en confluencia con la contaminación o renovación de estímulos por préstamos mediterráneos. 


\section{Otra alternativa}

Esta resumida trayectoria pone en guardia acerca de la dificultad en hallar el camino o la fuente de los modelos que inspiraron el vaso del Tossal Redó. La idea parece estar en el substrato indígena (recurrencia entre los dos hallazgos aragoneses y el de Mailhac) y expresarse por los modelos en boga y la maestría del ceramista. Como se ha visto, las particularidades, lejos de costreñir el área de analogías, rebasan la vía estrictamente mediterránea y nos conducen a un encadenamiento mental y técnico que, de momento, enlaza y enmascara cualquier rasgo genuino, pero apunta, aunque la puntualización sea difícil, hacia la Península Italiana. En efecto, Italia no pierde la continuidad de relaciones con Oriente, bien constatadas en poca micénica y es notable la antigüedad de las colonias griegas (especialmente Pithekousai) y el peso de los colonos y productos de la Grecia del Este, así como la incidencia y precocidad de los establecimientos fenicios de Sicilia y Cerdeña. Además, es obvia la interrelación entre los diferentes círculos italianos y el impacto oriental (incluyendo la instalación de artesanos) en la culturas de Etruria y el Lacio. Por otra parte, coincidiendo con el auge de la decoración a pincel, cobra mayor realce en la Italia peninsular e insular la fantasía de las formas y los adornos plásticos en recipientes y objetos de cerámica y metal, incluida la imitación y recreación de los calderos metlicos que desde Urartu se difundieron por el Mediterráneo Oriental, Etruria y Occidente y que como sabemos eran colocados en trípodes o podían tener como complemento una base acampanada. La convergencia de la fecunda creatividad Itálica y de los lujosos productos venidos de Oriente favoreció el capricho de elementos que contaban ya con arraigada tradición. El pie hueco es normal en la alfarería itálica, pródiga en formas de cuerpo globuloso y apenas cuello (Fig. 5, 1 a 3). El denominado tipo indígena "anfora/anforetta" perdura largo tiempo con gran libertad respecto a la altura del pie, situación de las asas o carencia de asideros. Según los ambientes, las asas pueden adoptar barrocas y caprichosas formas (animales, prótomos, miembros humanos...). En este sentido, ingenio y capacidad de recreación dieron paso la peculiar cerámica enotria y a la personalidad de estilo italo-geométrico (Akerström, 1943) de parco repertorio (tomado del tardo-geométrico griego), pero fecundo en variantes. Los nuevos estilos se adaptan al gusto local que impone en la selección y trasformación de los motivos el gusto autóctono y la preferencia por determinados temas de corte más continental y adriático, hasta llegar al geometrismo extremo, auténtica abstracción, y al desmembramiento de las formas. La denominada cerámica daunia (Juliis, 1977) puede servir, precisamente, como paradigma de esta tendencia generalizada y del alcance final de la decoración geométrica.

Los productos circularon libremente fomentando los regionalismos y la cultura atestina no fue ajena a esta circulación ya que, a partir del s. VIII, juega el papel de enlace entre los Alpes y Tarquinia y ejerce una verdadera ósmosis con las poblaciones circumalpinas hasta el punto de confundir, en un aparente patrimonio común, la ideología hallsttática y la de las poblaciones indígenas de Italia. Para el tema que nos ocupa los paralelos pueden ser múltiples, pero dado que la bibliografía es bien explícita (fundamentalmente Akerström, Hencken y Martelli) valoro globalmente las analogías formales y la tendencia a los registros horizontales, monotemáticos, adaptados a la arquitectura de la vasija y a la zona de sombras. Así, ceñidos en el ambiente etrusco/lacial, basta recordar los numerosos askoi zoomorfos y con decoración geométrica de clara influencia eubea, la abundancia de prótomos en sítulas, como la de bronce procedente de la tumba 22 de Bisenzio (s. VIII), y la profusión de todo tipo de apliques zomomorfos en el ajuar de las tumbas de Palestrina y Cerveteri.

Aunque son numerosos los askoi de forma bovina o los protomos de toro, con o sin largos cuellos, cabeza abocinada troncocónica y realismo de cuernos y orejas, no he localizado ningún paralelo 


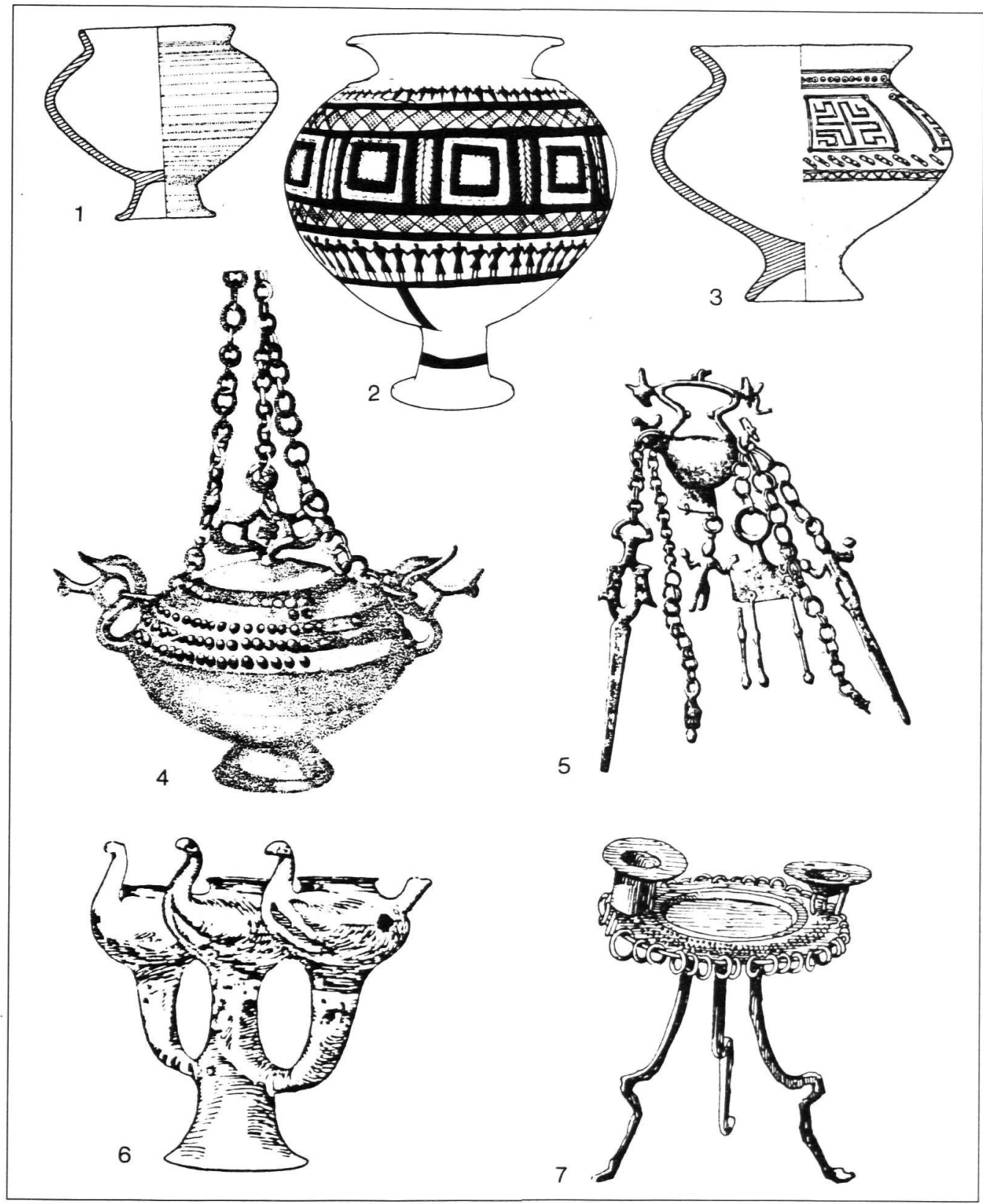

Figura 5.1 a 3 : Vasos globulares del Hierro I de Italia (el núm. 2 con pintura geométrica procede de la necrópolis de Bucacce da Bisenzio). 4: Incensario de bronce (¿Vetulonia?). 5: Colgante procedente de Novilara. 6: Vaso múltiple procedente de Como. 7: Mesa ritual metálica localizada en una tumba de guerrero procedente de Corneto. (sin escala). 
cerámico que se ciña exclusivamente a los apéndices de la cabeza y la cola de un cuadrúpedo, aunque sea normal la referencia ornitomorfa. El exponente más paradigmático, remedo de los colgantes del Hallstatt (Kossack, Lám. 11), es un vaso de la cultura de Golasecca procedente de Como (Randall, Lám. 20, 13) con pie acampanado y triple cuerpo esferoide rematado individualmente en esbelto cuello de ave y cola explayada (Fig. 5, 6). Las características de borde y boca se aproximan al vaso aragonés y los apéndices arrancan de la parte alta, junto al borde (con mayor estética que en el citado ejemplar de Ampurias). La morfología individual de cada vasija repite la silueta de un bello vaso procedente de uno de los túmulos frigios de Gordion (Lloyd, 1971, Fig.135), yacimiento que ha proporcionado un buen número de recipientes con protomos de toro. La boca de la vasija frigia, como la de otros recipientes italianos, es elipsoidal y la decoración, geométrica y pintada, realza, con recursos diferentes al vaso del Tossal, el pecho del pájaro. Este paralelo sirve para enlazar el ejemplar de Golasecca con recipientes tan antiguos y característicos como los localizados en las necrópolis boloñesas o en la de Monterozzi (Tarquinia): askoi híbrido ornitomorfo y bovino (Fig. 4:6) o incensario de bronce montado sobre ruedas, que mixtifica las figuras de ave (cuerpo, cola y cuello) y toro (patas y cabeza con cuernos) (Fig. 4, 5). Los precedentes, en línea con numeroso ejemplos del centro y norte de Italia, enraizan, como se ha dicho, con viejas costumbres continentales (p. e. carro cultual de Eiche, Potsdam) que gustan de aparatosos objetos de culto con alusiones acuáticas (barcas, ánades...) unidas a cabezas o figuras astadas cuya ideología se trasluce en el recargamiento plástico de numerosos objetos hallados en territorio italiano e insular (fundamentalmente Cerdeña), acrisolando en la fantasía local los ancestros y la renovación de las ideas.

Pese al parecido morfológico con los ejemplos mencionados nuestro vaso resulta diferente, pero en esta confluencia de relaciones puede estar su inspiración, máxime si tenemos en cuenta que coincide la forma troncocónica de la cabeza y la curva dorsal, rasgos recurrentes en los protomos zoomorfos de los askoi italianos de Bolonia o Tarquinia y en otros ejemplares datables en los siglos VIII/VII a. C. Además, desde Veyes II B (a partir del s. VIII a. C.) se documenta la representación bidimensional del pájaro podo con cuerpo rayado y se asiste al impacto eubeo y, en general de las primitivas colonias griegas, en el desarrollo de las diversas corrientes de la cerámica pintada de estilo geométrico (con imitación de formas metálicas y preferencia por motivos y organización análoga al vaso del Tossal: Cancini, 1974/5, 80), ancladas en la tradición griega tardogeométrica.

Esta idea del foco italiano se afianza al comprobar la hilera de pájaros ápodos llevados al máximo grado de lo geométrico -zigzags entre líneas conformando triángulos y apéndice angular para indicar la cabeza- presente en la tapadera de una sítula metálica procedente de la tumba 234 de Casa di Ricovero (Frey, 1968 Lám. 8, 10), fechada en Este III B2, entre 625-575. Además, los remates en dos cortas paralelas a modo de F se datan, cuando menos, desde la fase I del subgeométrico daunio (700-550 según Riis) unidos a un variado repertorio geométrico que gusta de los temas en losange.

Asas y función del recipiente. Las asas zoomorfas tienen larga tradición en el Mediterráneo (Bronce chipriota p. e.) y su presencia persiste aunque el tamaño del recipiente crateras y ánforas del geométrico griego- limite su función. En Italia, sin embargo, nunca son ociosas porque tienden a soportar adornos complementarios o a reforzar otras asas. Algo semejante pudo ocurrir en el vaso estudiado ya que el fácil apoyo del pie y la aparente debilidad de las asas respecto a la capacidad del recipiente, pone en duda la funcionalidad exclusiva de los apéndice como elemento de prehensión para el trasporte (más fácil si se sujeta el cuerpo con ambas manos). Por ello es razonable suponer que las perforaciones estuvieran destinadas a pasar algún elemento, a manera de cadena o soga, para facilitar la suspensión, o que, al igual 
que en muchos objetos hallsttáticos o en numerosos vasos plásticos de Italia (o en los calderos urárteos), sirvieran para colgar anillas móviles.

Incluso no descarto, por la rotura de las orejas, la doble posibilidad, tal y como muestra un curioso colgante de Novilara (Fig. 5, 5), afín a los ya citados del Hallstatt, que representa en miniatura una vasija con protomos zomoorfos (de morfología idéntica al vaso del Tossal) con asa vertical móvil y multitud de adornos colgantes (Randall, Lám. 25, 6), remedando los clásicos incesarios metálicos provistos de cadenas (ejemplos de Vetulonia, Novilara, Como, Bolonia...) de cuerpo esferoide y pie hueco, asas plásticas y estrecha boca con tapadera (Fig. 5, 4).

La particularidad de la boca del vaso "teromorfo" de Tossal Redó y lo inapropiado del borde para verter el contenido o acceder al interior, unido a la conjetura de que las perforaciones de las asas sirvieran para suspender el recipiente, inclina a la hipótesis de que cumpliera funciones análogas a los "turibula" o incesarios itálicos que frecuentemente se ornamentan con asas y apliques figurados y que por su trascendencia se convierten en amuletos de las poblaciones indígenas más fieles al substrato. Este tipo de recipientes, afectado por la creatividad local, lleva hacia ambientes europeos y no orientales en sentido estricto y su localización en tumbas o contextos religiosos, enfatiza, en unos u otros círculos, su destino ritual.

La personalidad y el capricho, según talleres, hace que cada pieza sea formalmente distinta y conceptualmente uniforme. La paradoja se explica por el modo de mixtificar y adaptar modelos orientales entre comunidades europeas que comparten una tradición común, vigorosamente enriquecida por la fuerza de la creatividad itálica y la conjunción renovada del peso mediterráneo.

Sintesis. Pese a reconocer la ascendencia oriental de la morfología plástica y muy especialmente de la teoría geométrica y de los motivos elegidos, y pese a los muchos paralelos que dentro de España existen para algunos motivos individualizados, comunes a diversas técnicas y materias, las matizaciones llevan hacia una sintaxis diferente, en la que se debe valorar la reserva de las zonas en sombra y la inversión de la línea en zig-zags respecto a la hilera de aves (en este caso, a diferencia oriental, superpuesta a los pájaros y no por debajo).

Dado que estos rasgos, incluyendo forma y modalidad de la cabecita, así como los meandros rectilíneos que, en diversas técnicas aparecen en las cerámicas de Mazaleón, son normales en las cerámicas alpinas e italianas, con o sin decoración pintada y en recipientes de metal, me inclino a considerar la Península Italiana como foco trasmisor/inspirador. En ello abunda la particular asociación bóvido/ave (incluso barca si se toma en tal sentido la forma aquillada), vetusto patrimonio de una ideología de cariz continental, de la que también participa el vaso con apéndices bovinos del Tossal Redó. Todo ello dentro de la profunda problemática de discernir hasta dónde llega la creatividad autóctona y las hibridaciones, y si los modelos llegan directamente por la vía marítima, apoyada o no en las islas o sufren contaminaciones al penetrar por el Norte, siguiendo viejas y frecuentadas rutas transpirenicas, tal y como se infiere de un buen número de hallazgos localizados en el NE. español y en el valle del Ebro (6).

(6) Sorprende la ausencia de fíbulas serpentiformes y el vacío de hallazgos, pese a la esporádica presencia aguas arriba del Ebro, de imitaciones que apuntan hacia la propia Italia. Tal sería el caso de las fíbulas de bucle y escalera, de los soportes lobulados de Cortes de Navarra, de las aves excisas en las cerámicas del Redal, remedo de los "birdbowls" eubeo-cicldicos tan bien representados en Italia, etc. 
La singularidad de la vasija del Tossal aboga por un destino ritual y es de notar que comparte con otros incensarios o perfumadores de Italia Septentrional no sólo rasgos formales sino la asociación a los animales preferentes y la constancia de la boca estrecha (la forma elipsoidad se comprueba ya en los viejos vasos plásticos del área transdanubiana y cárpata). La posibilidad de elementos colgantes se refuerza también por el "ocioso" taladro de la cabecita del vaso de San Cristóbal de Mazaleón. Incluso, aunque no sea definitivo para apoyar la conjetura de una asa vertical o móvil, que permitiera el balanceo, se puede aducir que las circunstancias del hallazgo de vaso de Tossal Redó presuponen su no deposición en el suelò.

\section{LOS MATERIALES DEL CONTEXTO}

Brevemente se tratan detalles de los materiales menos conocidos con objeto de evaluar conjuntamente los datos, intentando una aproximación mayor a las cerámicas "a torno" cuyas referencias claves, desaparecidos los fragmentos, constan únicamente en Inventario y registro del Diario de campo.

\section{La mesa de barro (Lám. III y Fig. 2, 7)}

Este raro ejemplo de "mesa" es de barro tosco mezclado con paja, menos rudo que el empleado en los revocos. Mide $18 \mathrm{~cm}$. de altura y los laterales están decorada con una banda incisa (surcos) de doble ángulo corrido, flanqueados por paralelas. Pese a conservarse menos de la cuarta parte, es presumible que la plataforma fuera cuadrangular y apoyara en cuatro pies troncocónicos, idénticos al conservado, ostentando en las esquinas pequeños apéndices huecos (fragmentados) a modo de "kotiliskoi" (5,5 cm. de diám.).

La técnica conlleva ciertas dificultades, pero materia y aspecto hojaldrado denotan un objeto de bajo precio y de aparente inconsistencia.

Adelanto que morfológicamente coincide con mesas para ofrendas o "altares porttiles" y el único testimonio español que sirve de precedente para este uso (dejando al lado el hallazgo en el dolmen de la Zarcita) es la fragmentada "mesa redonda de barro" del antiguo santuario de Cástulo (Blázquez y Valiente, 207, Lám. II, 2) cuyo aparato cultual relacionan los autores con el santuario chipriota de Ayia Irini (fase geométrica y arcica).

Efectiaimante, el testimonio de pata y vasito en una esquina remite a mesas de ofrendas, rectangulares o cuadradas, variando la disposición y el número de apoyos y vasitos, así como a "kernoi" con patas, ya sen de Vounos, Lapithos u otros yacimientos (Gagniers y Karageorghis, 1976,Lám. XXXVII, XL...) fechados en el bronce antiguo de Chipre ("Red Polished" estadio III). Tienen parangón con ejemplares minoicos y con la serie de mesas de piedra procedentes de Anatolia, Siria y Palestina, adornadas con cabezas astadas, que siguen funcionando durante el primer milenio (Buchhölz, 1980/81, 63, Fig. 16 a 18).

El camino hacia Occidente es idéntico al de los vasos plásticos; mesas de barro con pies se conocen en el Bronce yugoslavo (Kóvacs, 1972, 24-25) y reaparecen en los contextos funerarios hallsttáticos, asociadas a excepcionales vasos con o sin protomos zoomorfos. En Italia del Norte este tipo de altares se documenta en la necrópolis villanoviana de Contrada Forchetta di Palano y, además de los llamados "vasos de presentación" (con cuatro patas), desde la fase de Benacci II hasta la fase Arnoaldi, en sincronía con hallazgos semejantes en otras culturas noritlicas (siglos VIII-VII) se depositaron en las grandes tumbas de Bolonia sofisticadas mesas de metal de uno o más pies y varios cuenquecillos (tumba 39 de Benacci-Caprara y tumba 494 del predio Benacci: 


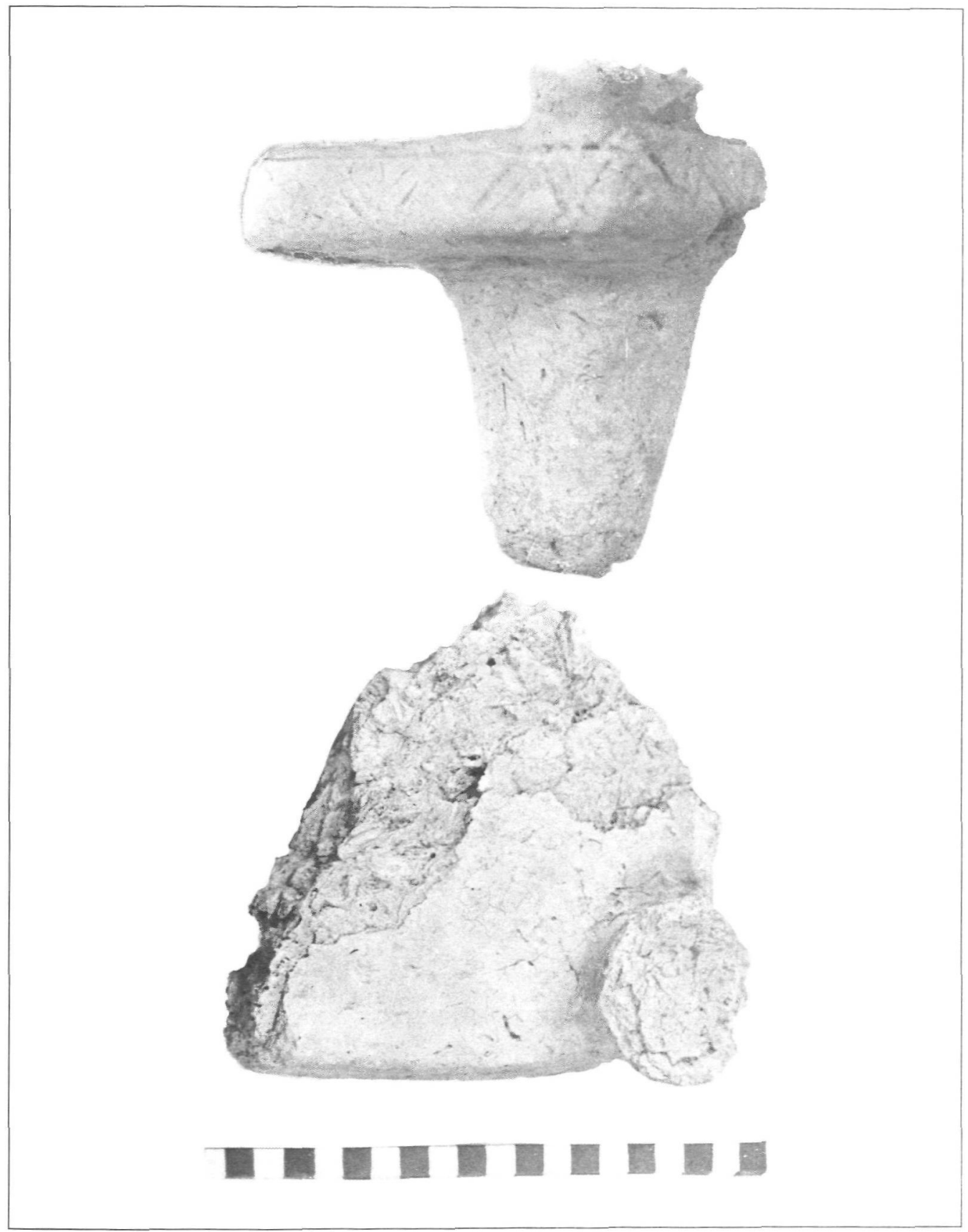

Lámina 3. Mesa de barro de Tossal Redó. 1: Vista de la plataforma y el arranque del cuenquecillo. 2: Vista vertical. 
Frey, 1969, Fig. 12 y 13), que tiene su réplica en otros modelos como el ilustrado en la Figura 5, 7.

\section{Cerámicas a mano y objetos de metal}

En fotografía publicada por Bosch (1913-14, Fig. 59a) se comprueba mejor que en el Diario la decoración en relieve de los fragmentos núm. 332, comunes a diversos yacimientos de la zona, al igual que el resto de las vasijas a mano. Dentro de la cerámica atribuible a la excavación de prueba (Lám. IV y V) únicamente merece destacar la rareza de la vasija carenada (Lám. IV, 1 y Fig. 2, 5), reconstruída posiblemente a partir del fragmento núm. 329 del Inventario. Recuerda a los finos vasitos de los inicios del Hierro I en el Sudeste aunque, junto con el vaso núm. 327 del inv. (Fig. 3, 4 y Lám. III, 2), forma parte de la serie francesa de "gobelets".

En los metales (Fig. 3, 1 a 3), aparte de remarcar la presencia de la plaquita de hierro, destaco la singularidad del botón semiesférico con travesaño en cruz. Mide $40 \mathrm{~mm}$. de diámetro y 20 $\mathrm{mm}$. de altura, es hueco, posiblemente fundido, y lleva encajadas en el reverso dos barritas en aspa. Su función, a modo de falera, se vincula al arnés de los caballos. Actúan como pasacorreas de los montantes del cabezal y, en este caso concreto, estamos ante un modelo equivalente a los botones de una barra o de pie anular. El tipo es raro en la Península Ibérica y el único ejemplar, que al parecer era idéntico, se localizó en una cista próxima en término de Mazaleón.

El origen debe buscarse en Europa Central, alcanzando el occidente al final del s. VIII a. C. aunque las propuestas cronológicas de distintos investigadores franceses (Mohen, Courtois, Guilaine, Roudil...) son coincidentes en situar su auge durante el s. VII (período II de Aquitania y fase II de Mailhac/Grand Bassin I) llegando hasta el siglo VI, como se desprende algunos contextos funerarios y de la asociación a materiales "launacienses", calificación extensible al pecio de Rochelongue (Cap de Agdé) en donde se hallaban buen número de botones con travesaño en cruz.

\section{Cerámicas a torno}

Este apartado ofrece mayor novedad y es ciertamente comprometido por cuanto se trata de interpretar las referencias del inventario.

De las 34 casillas que registran hallazgos cerámicos (en muchos casos contienen más de un fragmento o los vasos enteros ya restaurados) solamente ocho especifican que se trata de cerámicas a torno (el número 298 es un asa bífida localizada en superficie, sin indicar el lugar exacto). Como procedentes de la Habitación 1 propiamente dicha se califican como cerámicas a torno los siguientes números de Inventario (Vide dibujos del Diario):

-Núm. 342. Puede tratarse de la boca de un ánfora fenicio-púnica de corto cuello y hombros marcados.

Núm. 343 (Pág. 45). Tapadera con botón cónico. Relacionada con el dibujo núm. 344, "fragmentos con asita perforada", hace pensar en la típica tapadera que cierra las consabidas "urnas de orejetas". El modelo aparece en el poblado de San Cristóbal de Mazaleón (Fig. 6, 5).

-Núm.. 344. Con una raya pintada. El fragmento Núm. 7 de la Fig. 6 (materiales de San Cristóbal) repite el hallazgo.

Núm. 345. Tres asas, dos de ellas claramente bífidas. Este tipo de asas es característico de las importaciones coloniales y están documentadas en el vecino poblado de San Cristóbal de Mazaleón (Fig. 6, 2).

-Núm. 346 a 349 (sin dibujo). Fragmentos pertenecientes al cuerpo de un vaso cuya pasta es 

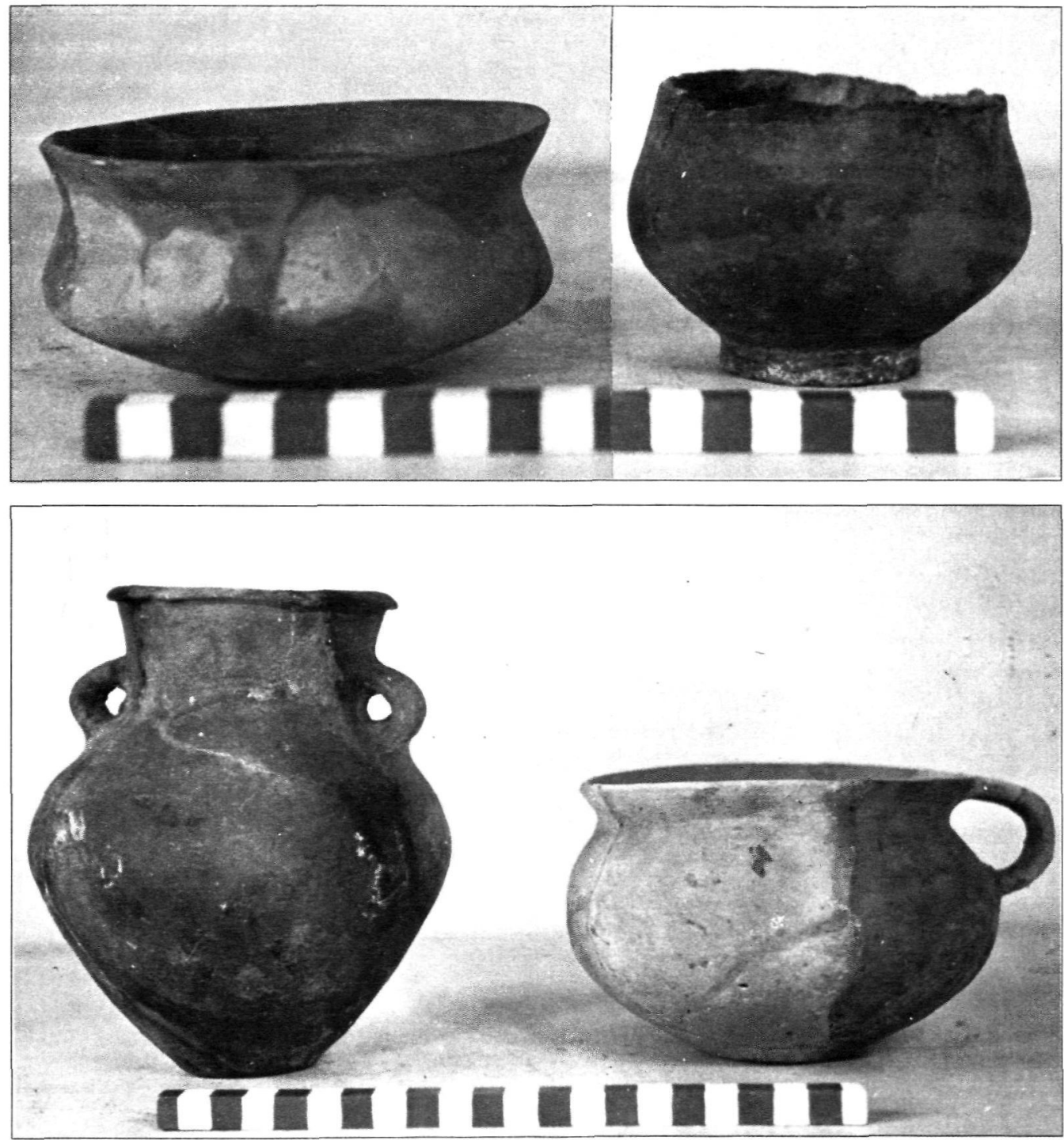

Lámina IV. 1, 2 y 4: Cerámicas a mano de Tossal Redó. Habitación 1. 3. Anforilla de tipo fenicio localizada en el mismo contexto.

"rosada" (Núm. 347) y de barro oscuro o "fosc" (Núm. 348-349). Nada extrañaría que se trate de la misma vasija en forma de ánfora (Núm. 342). Al menos el color del barro es coincidente con este tipo de piezas. A ello debe aludir Bosch (1913/14, 831) cuando atribuye diversos fragmentos a una "gran gerra"

Estas deducciones, ciertamente frágiles en argumentos teóricos y con todas las controversias que puede suscitar la interpretación de los dibujos, cobran valor si tenemos en cuenta la presen- 

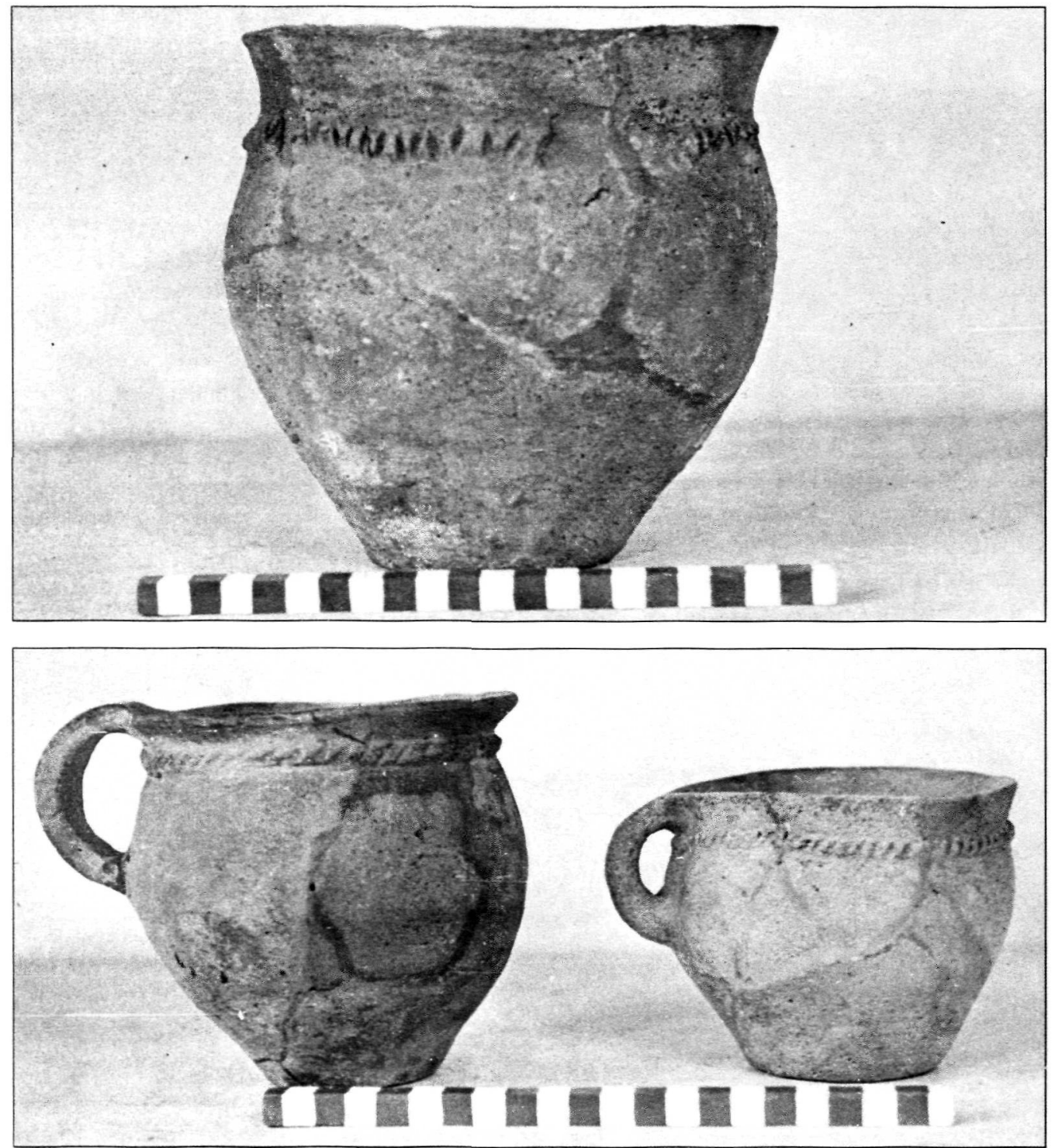

Lámina V. Cerámicas a mano localizadas en la Habitación 1 del poblado de Tossal Redó.

cia en el propio contexto de la anforilla fencio-púnica forma BII-b5 de Cintas (Inv. 317: Lám. IV, 3) estudiada por'E. Sanmartí (1975 y 1978) (7).

Estas cerámicas a torno, las únicas que se consignan por escrito en el inventario de todo el poblado Grande, llevan a la conclusión de que nos hallamos en el mismo ambiente cultural y cronológico que el poblado de San Cristóbal de Mazaleón (Horizonte Ibérico Antiguo I de San- 


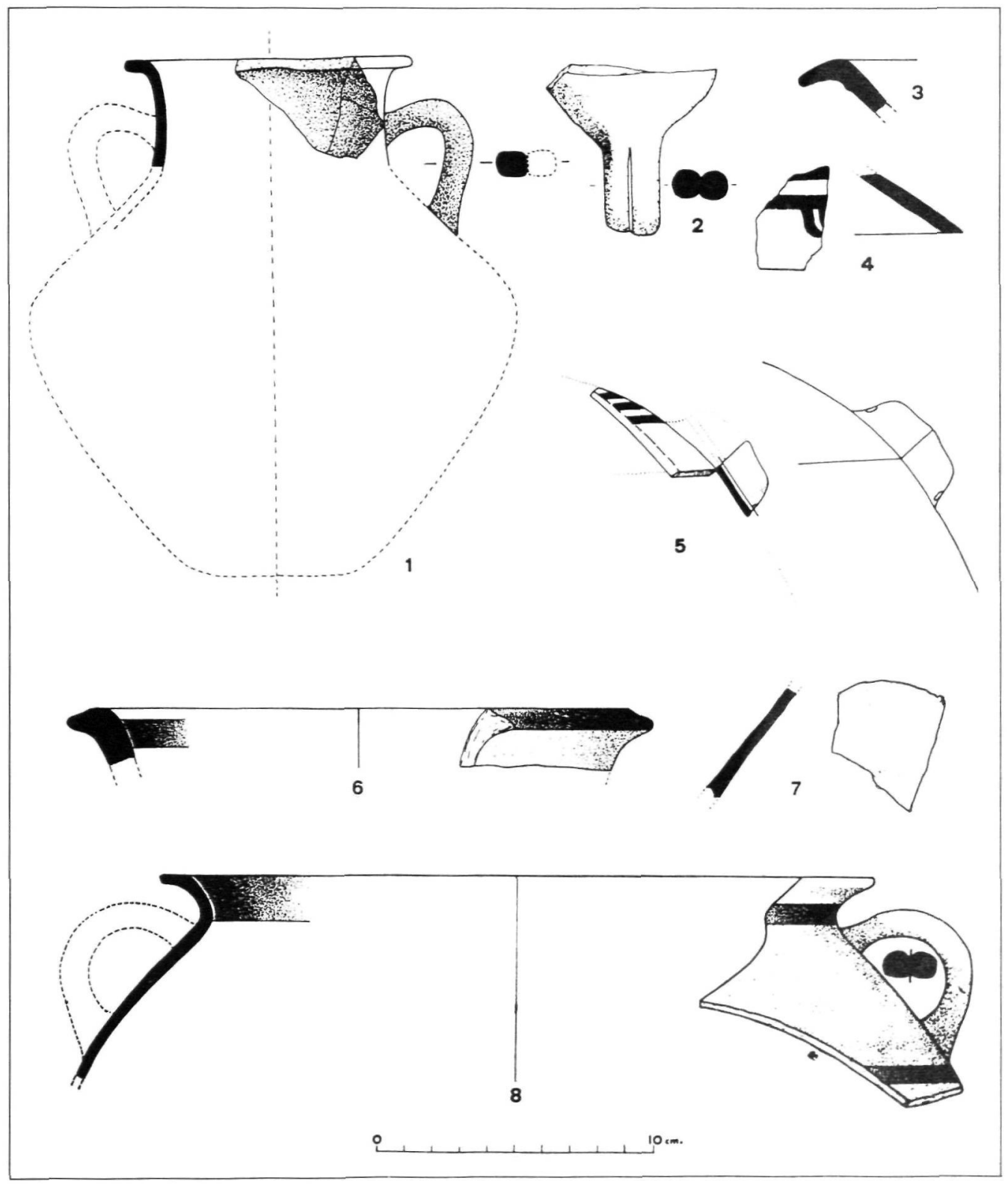

Figura 6. Materiales de procedencia colonial localizados en el poblado de San Cristobal (Mazaleón). Según Sanmartí y Padró (1977/78). 
martí y Padró, 1978) (8), extensible a las cistas del entorno. Es decir, posible fundación de los poblados entre los s. VIII/VII y funcionamiento hasta bien entrado el VI. El hecho de reconocer envases y alfarería de las colonias fenicias del Sur (o de Ibiza) no invalida los argumentos expuestos. Es más, confirma el comercio regular de la zona, muy próxima a la desembocadura del Ebro, y la existencia de comunidades capaces de adquirir, consumir y apreciar las nuevas mercancías, entre las cuales debía encontrarse el vino.

De ser ciertas estas conjeturas, es razonable suponer que tan preciados materiales (y su contenido) se almacenaran o depositaran en el espacio más particularizado del poblado: la única cámara semisubterránea con banco labrado en la roca. Es de lamentar que los hechos no permitan esclarecer si los fragmentos de barro decorados, hallados en la capa más profunda, conformaban el contorno de algún hogar o revestían un poste. Ya que no se trata de una tumba, y aunque la verificación sea imposible, a tenor de la calidad y naturaleza de los hallazgos de esta Habitación 1 (rareza del vaso con apéndices bovinos, mesa de ofrendas/altar portátil y recipientes foráneos), no es aventurado suponer que estemos ante un espacio dedicado al culto o a guardar los objetos sagrados. En este sentido hay que aludir al santuario de Cástulo (Jaén) y a las concomitancia del aparato en el cual también se advierte la confluencia de los elementos "indoeuropeos" y la savia del Mediterráneo.

(7) La pasta de esta discurida pieza es rojo-amarillenta con abundante "arenilla" y mica y ofrece en algunas zonas un fuerte tono rojizo, si bien predomina al exterior el color más pálido y pulido.

(8) Los fragmentos núm. 320 y 319 , descritos como de color amarillento, finos y a mano, guardan parecido con los frag. 1, 6 y 8 de San Cristóbal ¿̨Se trata de imitaciones o de dificultades en su identificación?. 


\section{APENDICE: COPIA DEL DIARIO DE BOSCH GIMPERA}

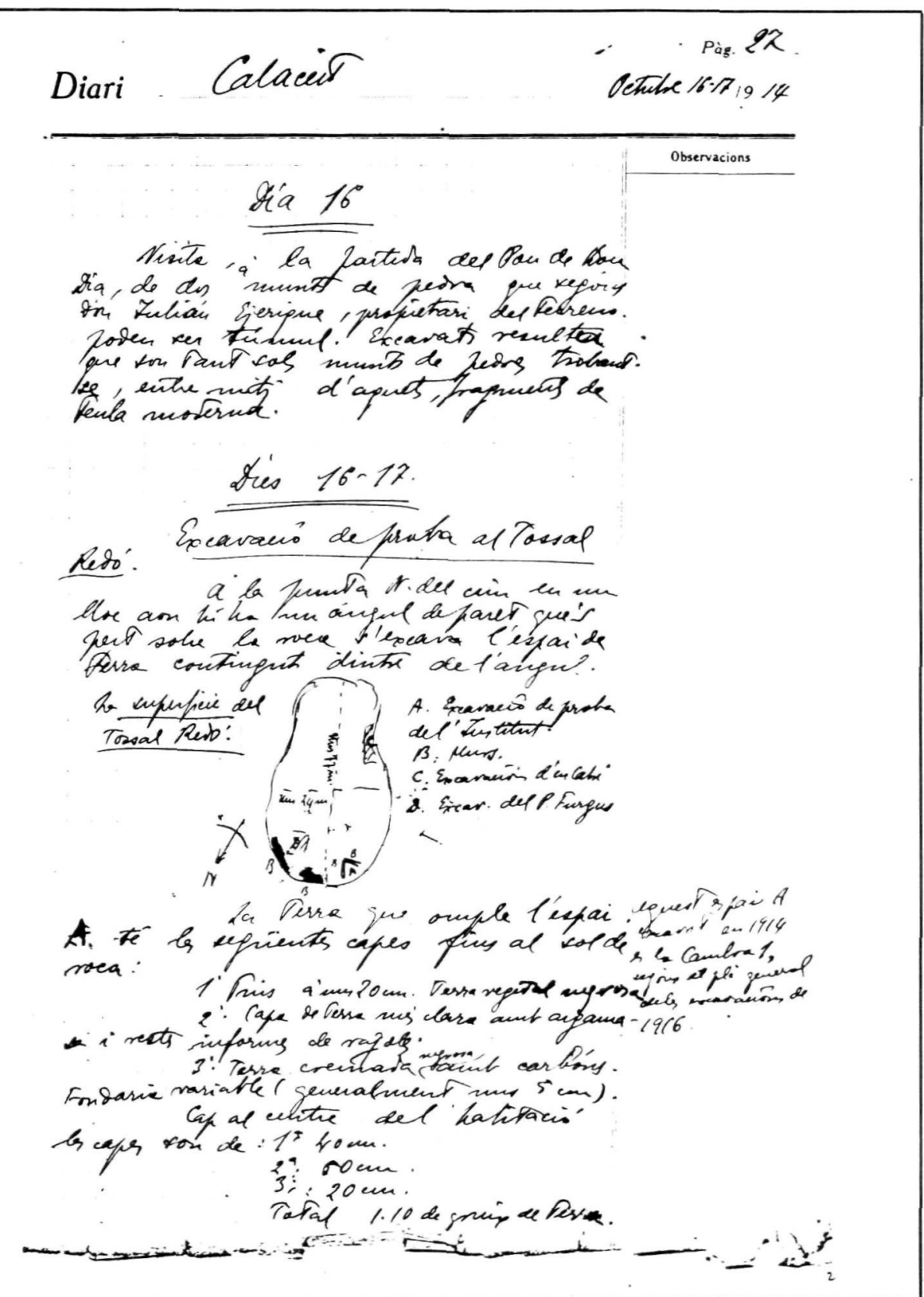


Diari Calaceit

Pag. 98

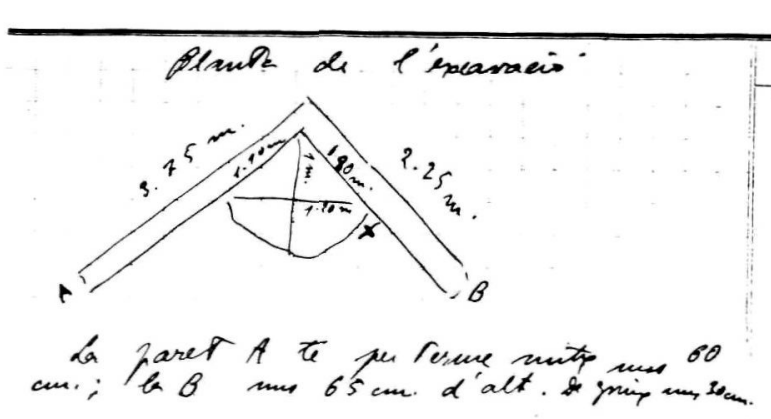

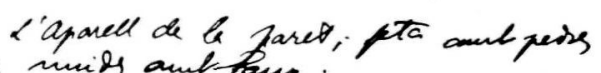

agus mids and fane.

Observacions .

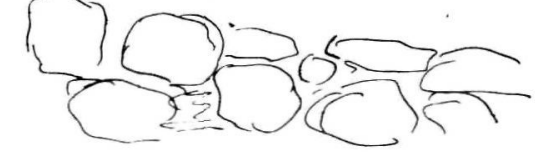

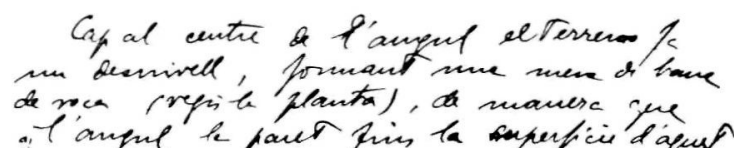

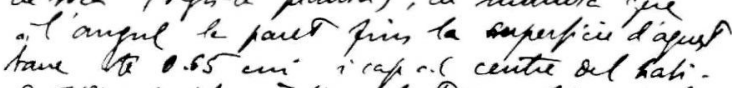

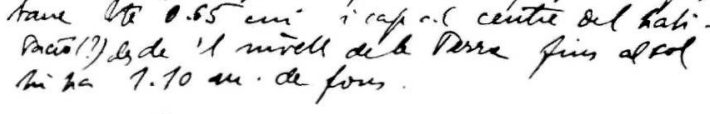

Leceis' in langel.

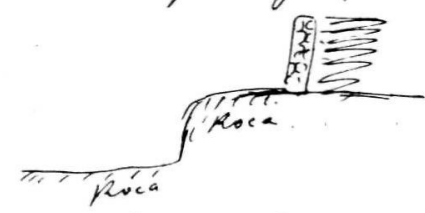

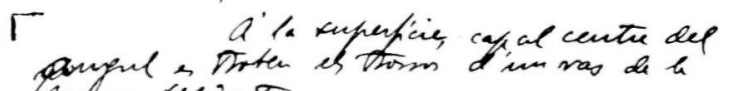

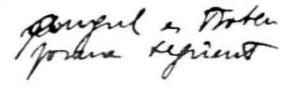

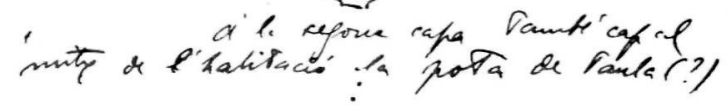

Zur. 927

200 
Diari Calaceit afane

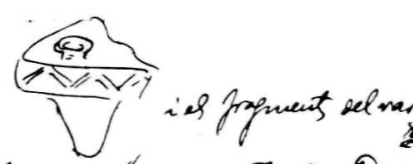

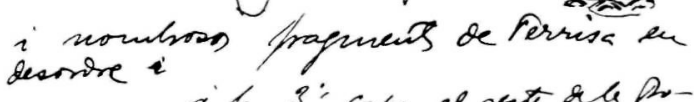

tralls a he 3i cafie el rate als pro-

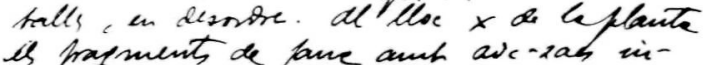
is frapments de tave aunh asc-rach inastor

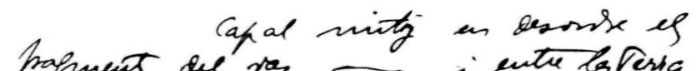
pagmens der vas

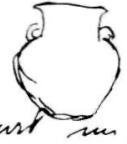

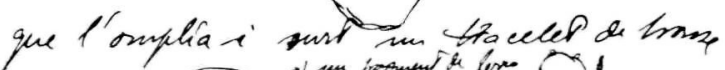

Octurbersis:9/4

$P_{\text {og. }} .9$

Observacions

$\operatorname{Lur} 3 / 5$

Zur. 332

zur. 310

2ur. 317.

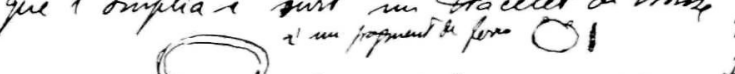

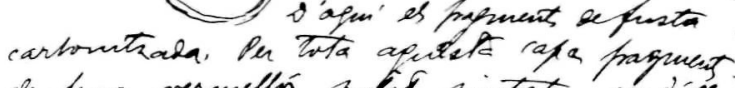

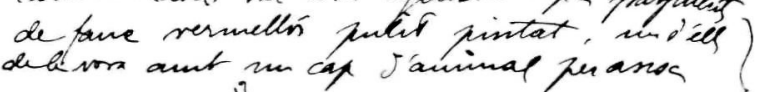

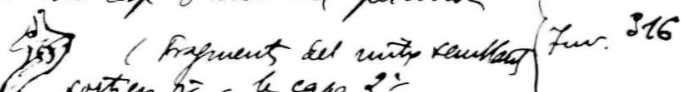

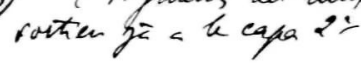

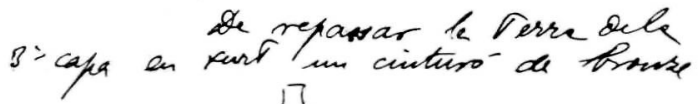

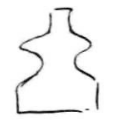

Zur. 305

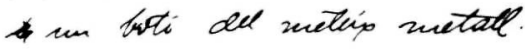

()

(2)

Zur 30

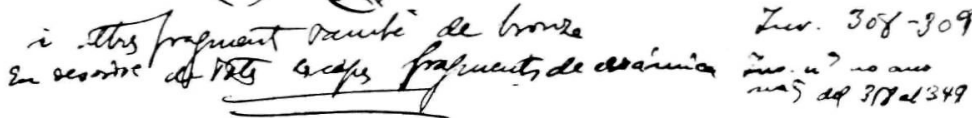

Zue. $308-909$

201 
Inventari del material arqueologic del Trssal Redó (Calaceirs)
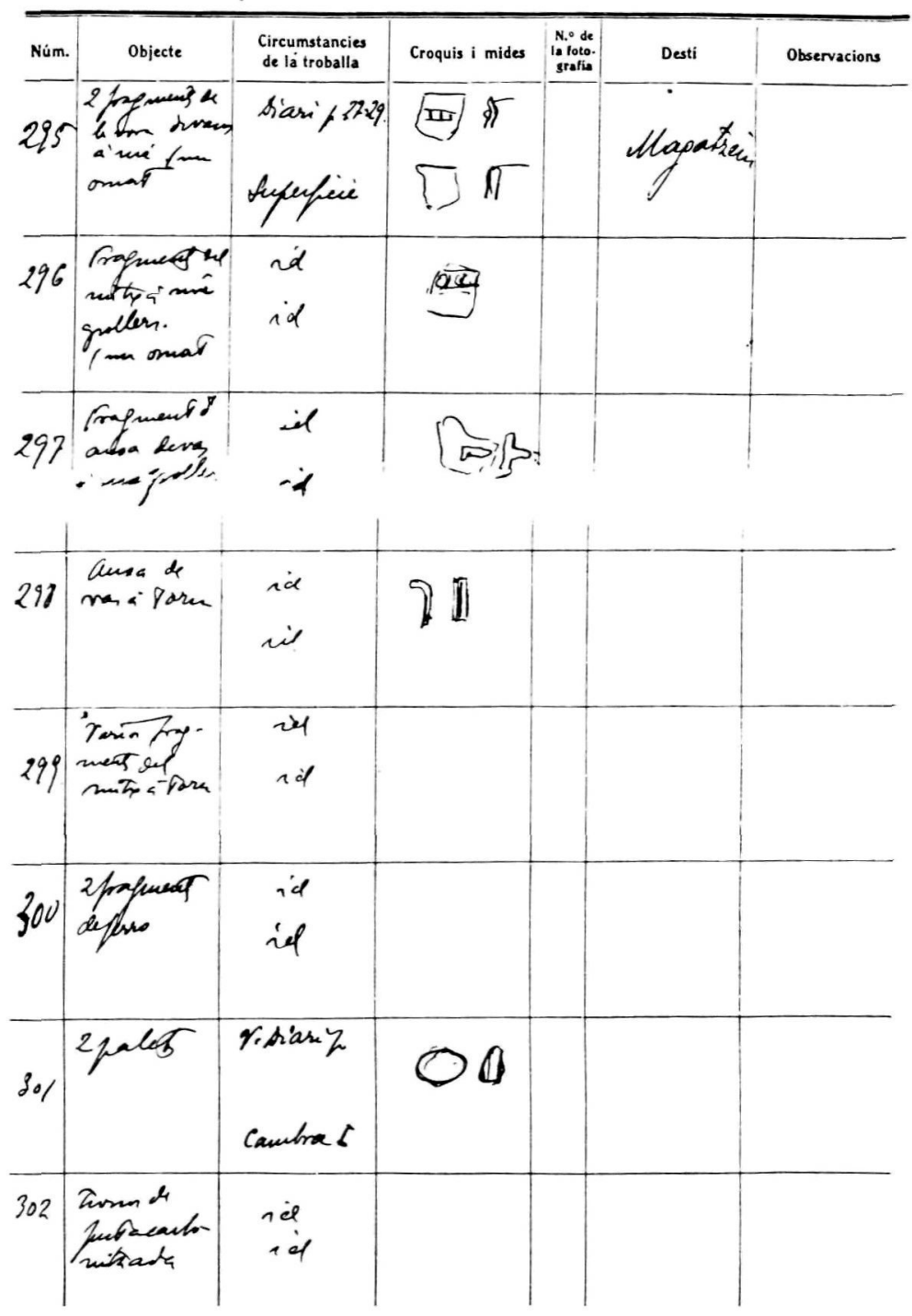

202 


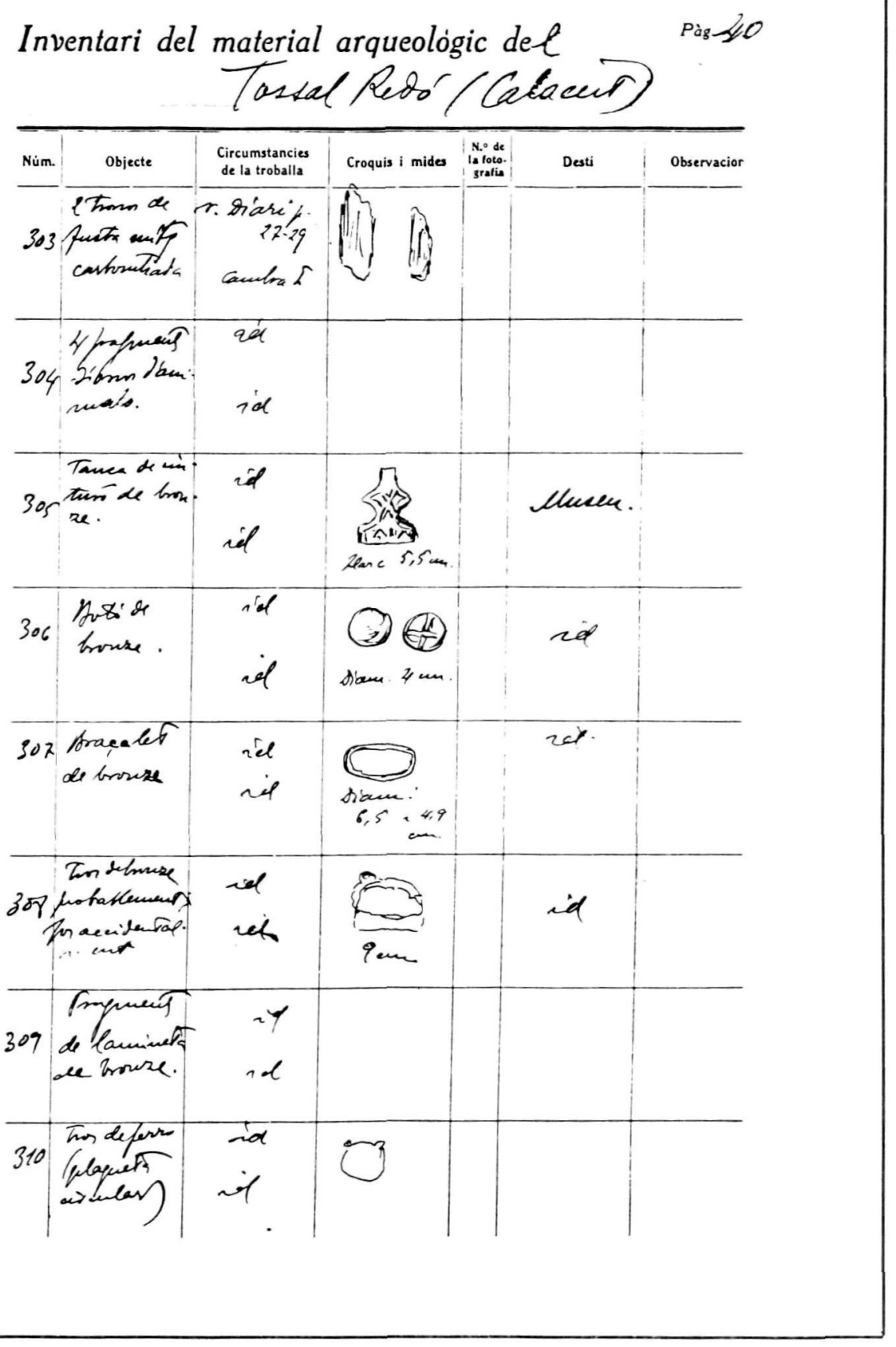

203 


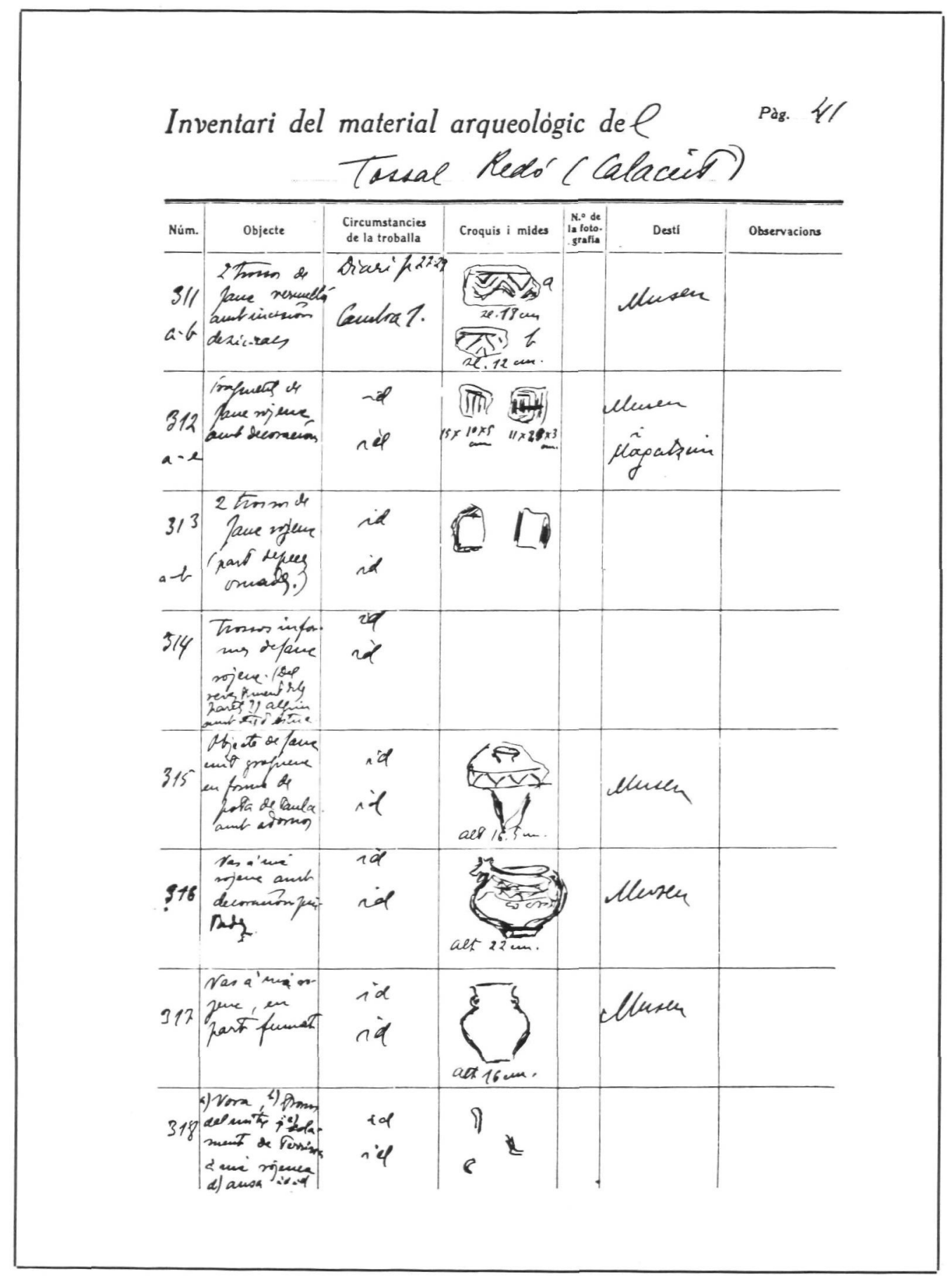

204 


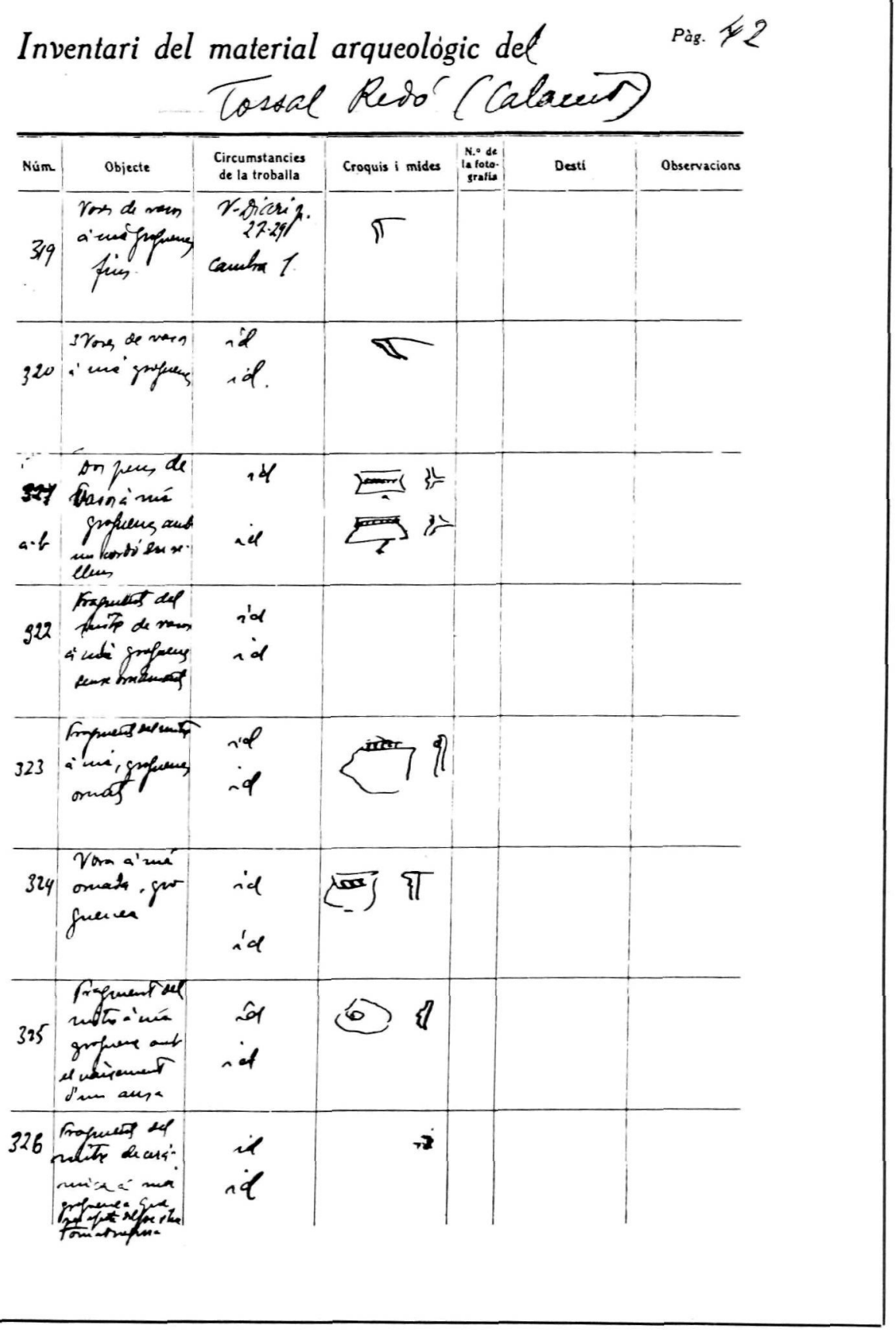

205 
Inventari del material arqueologic de $\rho \cdots$ Pag. $_{2}$

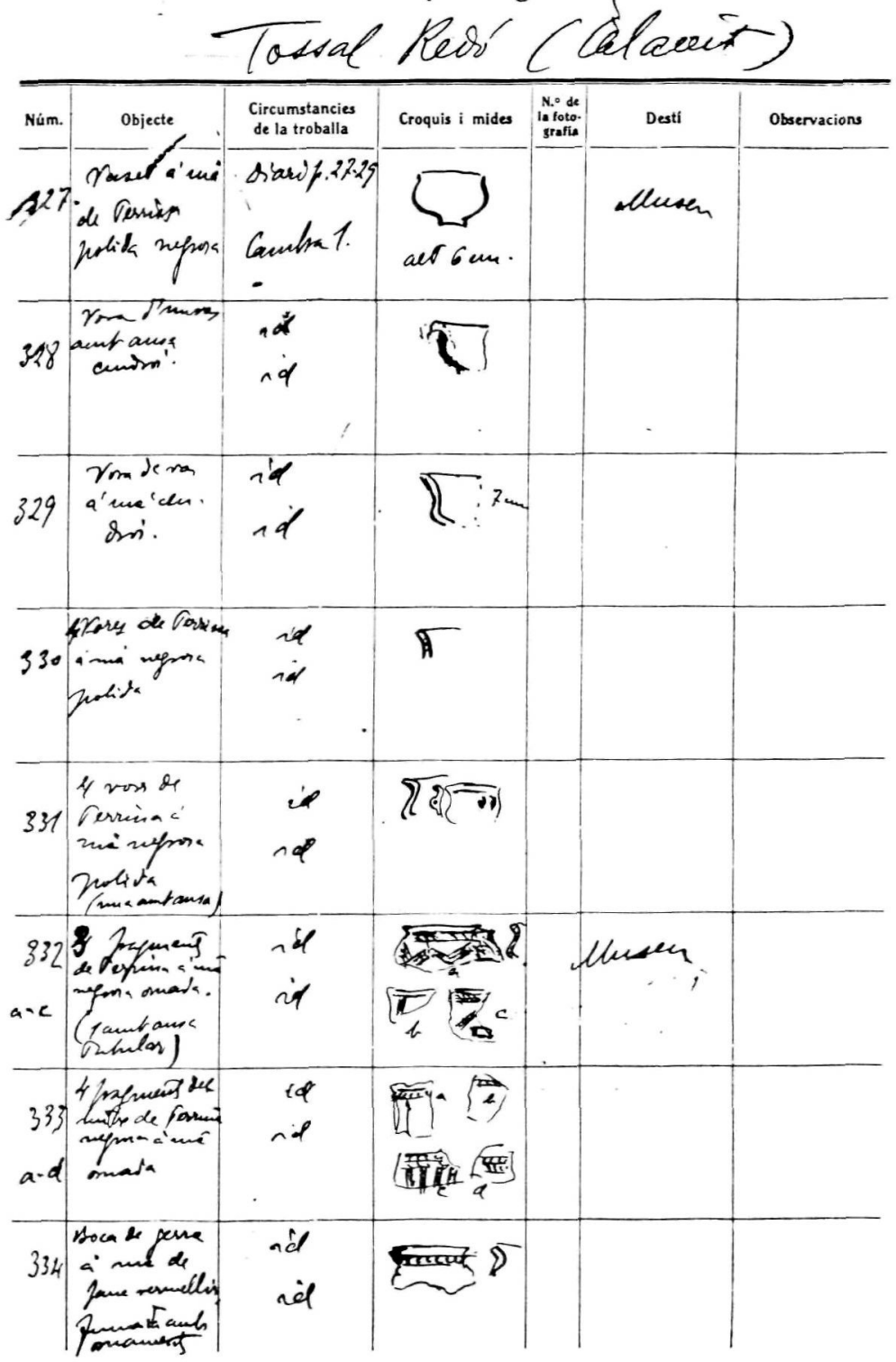




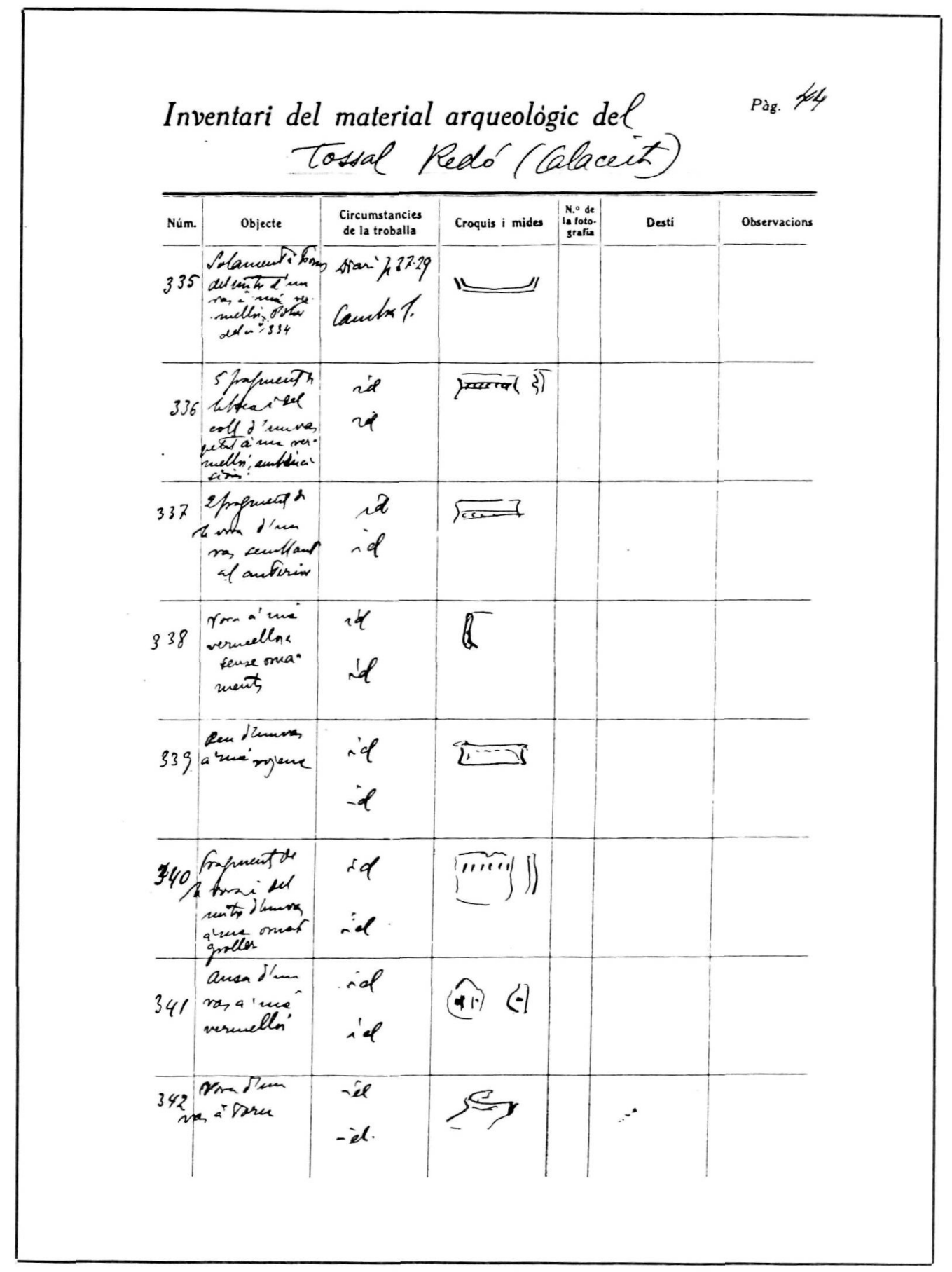

207 
Inventari del material arqueologic de $\ell \quad P_{\mathrm{ag}} \nVdash^{5}$ Tossal Redó (Calacut)

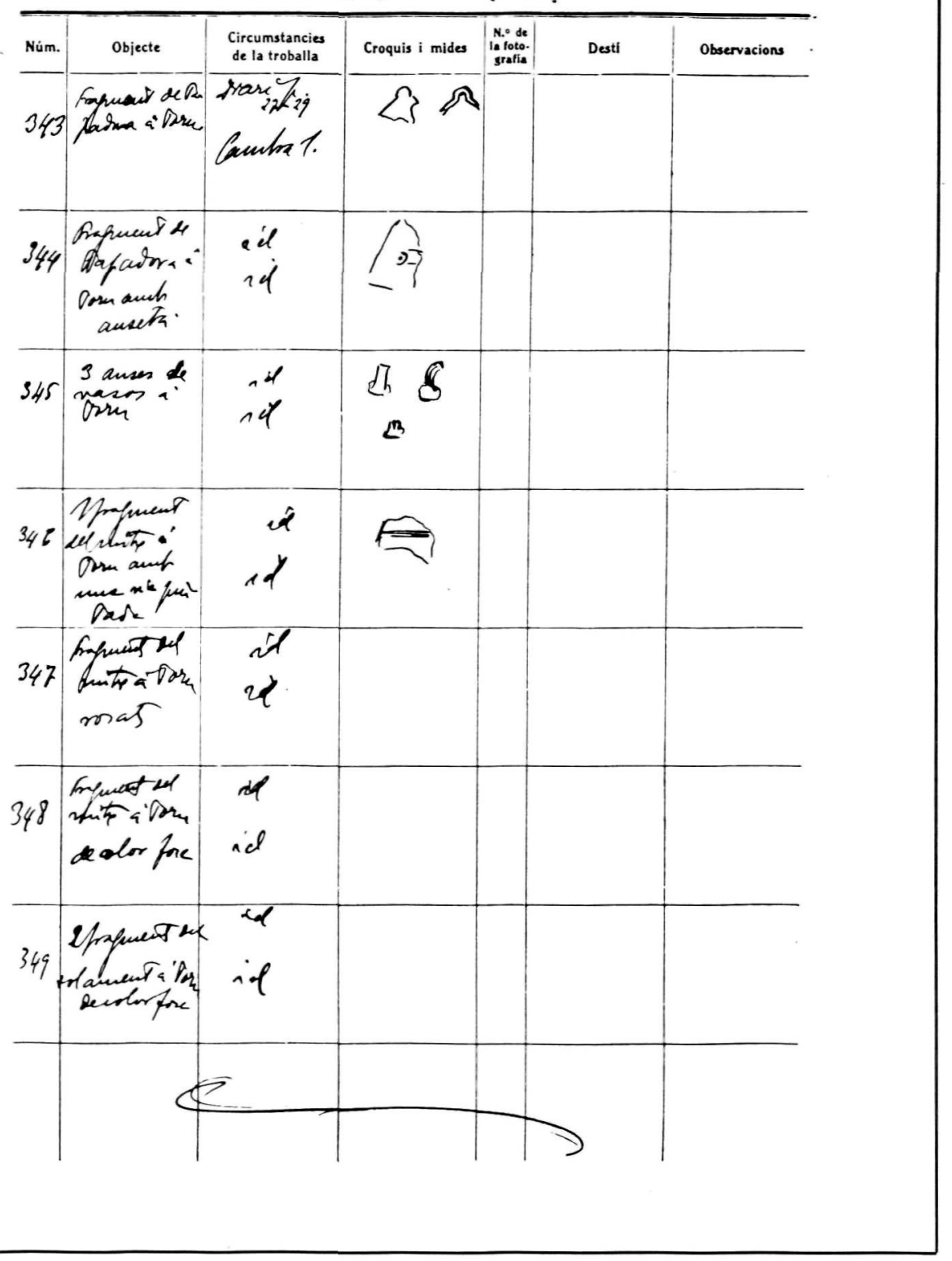

208 


\section{BIBLIOGRAFIA}

AKERSTRÖM, A. 1943 : Der Geometrische Stil in Italien, Lund

Almagro Gorbea, 1977: El Bronce Final y el Período Orientalizante en Extremadura, BPH, XIV, Madrid.

Alvarez, P. y Perez Arrondo, C. 1987: La cerámica excisa de la Primera Edad del Hierro en el Valle Alto y

Medio del Ebro, Logroño.

Atrian Jordan, P. 1961:“Cerámica céltica del poblado de San Cristóbal (Mazaleón,Teruel)”, Rev. Teruel, núm. 26, 229-246.

Ayoub, S. 1982: Die Keramik in Mesopotamien und in den Nachbargebieten, Mainz

Bartoloni, A. M.. et alii, 1980: Materiali dell'etá del Bronzo finale e della prima etá del Ferro, Florencia..

Beirao , C. M.De Mello, 1986: Une civilisation protohistorique du Sud du Portugal (ler Age du Fer), París

Beirao, C. M. . et alii, 1985: "Depósito votivo de Garvao", O Arqueólogo Português, serie IV, vol.3, 45-135.

BENDALA, M. 1977: "Notas sobre las estelas decoradas del Suroeste y orígenes de Tartessos", Habis, 8, 177-205.

BitTel, K. 1976: Los Hititas, Madrid.

BlazQuez Martinez, J.M. 1975: Tartesos y los origenes de la Colonización Fenicia en Occidente, 2a. ed. Salamanca.

BlazQuez,J.M. y Valiente, J. 1981: Castulo III, E.A.E. núm.117, Madrid.

Bosch Gimpera, P. 1913/14: “ Campanya arquelógica de l’Institut d’Estudis Catalans al limit de Catalunya i

Aragó” (Caseres, Calaceit i Maalió), Anuari I. E. C., Barcelona, 819-838.

... 1919, 1920: "Les investigacions de la cultura ibérica al Baix Aragó", Anuari I. E. C., 641-667.

BROCK, J.K. 1957: Fortetsa, Cambridge

Broncano Rodriguez, S, 1989: El depósito votivo del Amarejo. Bonete (Albacete), E. A. E. núm, 156.

BuchHolz, H. G. 1980/81: "Kälbersymbolik", Acta Praeh. et Arch. núm. 11/12, 55-77.

Buero Martinez, M. S. 1985: "Los motivos naturalistas en la cerámica pintada del Bronce Final del Suroeste Peninsular”, Habis, 15 (1984), 345-364..

Cabrera Bonet, P. 1981: "La cerámica pintada de Huelva", Huelva Arqueológica, V, 317-335.

.. 1986: "Los griegos en Huelva: los materiales griegos", Homenaje a Luis Siret, 575-583.

CANCINI, F. 1974/75: "Un biconico dipinto da Vulci", Dial. Arch., 8, 1, 79-85.

Cerdan, C. y LeiSner, G. y V. 1952: Los sepulcros megalíticos de Huelva, “Informes y Memorias", 26, Madrid.

CinTas, P. 1970 y 1976: Manuel d'Archéologie Punique, 2 vols., París

Coldstream, J. M. 1977: Greek Geometric Pottery, Londres

Dammer, H. W. 1978: “Die bemalte Keramik der Heuneburg," Röm.- Germ. Forsch., 37, Mainz.

Delpino, F. y Fugazzola, M. A., 1976: "Vasi biconici tardo geometrici", Arch. Clas. XXXVIII, 1-9.

Dobiat, C. 1982: "Menschendarstellungen auf ostalpiner Hallstattkeramik", Acta Arch. Hung. 34, 279-322.

FEKETE, M. 1985: Früheisenzeitliche Hügelgräber in Vaskeresztes, Acta Arch.Hung., 37, 33-78.

Frey, O.1969: Die Entstehung der Situlenkunst. Röm. Germ. Forsch. 31

GAGNIERS, J. Y KARGEORGHIS V. 1976: Vases et figurines de l'Age du Bronze á Chipre, Quebec

Garcia Y Bellido, A. 1948: Hispania Graeca, vols. I a III, Barcelona.

Gomez Bellard, C. 1990: La colonización fenicia de la isla de Ibiza, E.A.E. núm. 157.

HenCKen, H. 1968: Tarquinia, Villanovans and Early Etruscans, Cambridge (Mass.).

Joffroy, R. 1977: "Les civilisations de l'Age du Fer en Bourgogne", La Préhistoire Française, II (dir. J.Guil.AINE), París, 816-825.

Julils, E M. 1977: La ceramica geometrica della Daunia, Florencia.

Jully, J. y Nordstrom, S, 1966: "Le vase-oiseau du Cayla de Mailhac et ses similaires en Méditerraneé Occidentale” Cah. Lig. Preh, Arch., núm. 15, 259-282.

KoSSAK, G. 1954 : "Studien zum Simbolgut der Urnenfelder-und Hallstattzeit Miteleuropas, Röm.Germ. Forsch." núm. 20.

KovaCs, T. 1972: "Askoi, bird-shaped vessels, bird-shaped rattles in Bronze Age Hungary", Folia 
Archaeologica, XXIII, 7-28.

... 1981, "Bronzezeitlliche Tradition in der hallstattzeitlichen Kunst Transdanubiens", Symposium Styer, Linz, 65 - 85

Kromer, K. 1958 : Gemeinlebarn, Inv. Arch. Osterreich, 2

Lagrand, CH. 1987: "Le premier Age du Fer dans le Sud-Est de la France", en Hallstatt-Studien/Etudes Hallstattiennes (Tubinger Kolloquium zur westeuropischen Hallstatt-Zeit, (1980), Tubingia, 56-88

LuCas Pellicer, M. R. 1982:“El thymiaterion de Calaceite (Teruel)”, Bol. As. Esp. Am. Arq., 16, 20-28.

... 1987: "Dónde está la Primera Edad del Hierro", Bol. As. Esp. Am. Arq., 23,

Lucke, W. y Frey, O. 1962: Die Situla in Providence (Rhode Island).Ein Beitrage zur Situlenkunst des Osthallstattkreises. "Röm.-Germ. Forsch", 26, Berlin.

LloYd, S. 1971: Povos antigos da Anatólia, Lisboa (vers. original, 1967)

Maximova, M. I. 1927: Les vases plastiques dans l'Antiquité, 2 vols, París

Murillo, J. F. 1989: "Las cerámicas polícromas con decoración figurada y geométrica de La Saetilla (Palma del Río, Córdoba) en el contexto orientalizante andaluz, Ariadna, 6, 67-102.

Olmos Romera, R. 1986: "Los griegos en Tarteso: Replanteamiento arqueológico-histórico del problema", Homenaje a Luis Siret, 584-600

Pellicer Catalan, M. 1984: "La influencia orientalizante en el bronce final-hierro del nordeste hispano", Habis, 13 (1982), 211-238.

... 1985: "Elementos ultrapirenaicos y hallstattizantes en e horizonte del bronce final-hierro del Noreste hispano", Habis, 15 (1984), 309-341

RanDALl-MC IVER, D. 1927: The Iron Age in Italy, Oxford

Riedgway, F .R. 1969: "The Este and Golasecca Cultures. A Chronoogical Guide." en D y F. Ridgway, Italy Before the Romans. Londres.

RODANES, J. Ma . y ROYO, J. I. 1986: "Representaciones zoomorfas en la cerámica del Bronce final y Primera Edad del Hierro en el Valle Medio de Ebro", Estudios en Homenaje al Dr. Antonio Beltrán Martínez, Zaragoza, 373-387.

Rodero RiazA, A. 1980: Colección de cerámica púnica de Ibiza, Madrid.

Roulllard, P. 1978: "Les Céramiques peintes de la Grce de l'Est et leurs imitations dans la Péninsule Ibérique" en Colloq. Int.: Les Céramiques de la Géce de L'Est et leur diffusion en Occident (Nápoles, 1976), París., 274-286.

Sanmarti Greco, E, 1975: "Las cerámicas finas de importación de los poblados prerromanos del Bajo Ebro (Comarca del Matarranya)", Cuad. Preh, Arq. Cast. núm. 2, 87-133

... 1978: "Les cultures protohistriques de la comarca del Martarranya: un estat de la qüestió", Fonaments, núm. 2, 121-149.

SANMARTI, E. y PADRO, J. 1977/78: "Ensayo de aproximación al fenómeno de la iberización en las comarcas meridionales de Cataluña", Simposi Int. Els origins del món Ibèric, 156-176.

SCHUBART, H. 1979: "Morro de Mezquitilla. Informe preliminar sobre la campaña de exavaciones de 1976", N.A.H.núm. 6, 175-218.

SChubart, H. y MaAs-Lindemann, G.1984: "Toscanos. El asentamiento fenicio occidental en la desembocadura del río Velez. Excavaciones de 1971", NAH, núm.18, 39-210.

SCHWEITZER, B. 1971: Greek Geometric Art, Londres.

Taffanel, O.: 1962 : "Le premiere Age du Fer à Mailhac", Cah. Lig. Preh. Arch.,. núm. 11, 159-163.

Vence, H. P., 1981: "Zu einigen bildnichen Darstellungen der Hallstattzeit aus Nordbayern" en Die Hallstattkultur, Symp. Steyr 1980, 185-204.

WEISS, S. 1974: "Bronzezeitliche Tiergefässe aus der Uckermark", Nachr. für Vor. und Frühg. 19, 128-131

Werner, S., 1990: La Cerámica pintada geométrica del Bronce Final y de la Primera Edad del Hierro, Madrid. 